\title{
CHAPTER 2.4.
}

\section{INHERITED STERILITY IN INSECTS}

\author{
F. MAREC ${ }^{1}$, S. BLOEM ${ }^{2}$ AND J. E. CARPENTER ${ }^{3}$ \\ ${ }^{1}$ Institute of Entomology, BC CAS, České Budějovice, Czech Republic \\ Email: marec@entu.cas.cz \\ ${ }^{2}$ North American Plant Protection Organization, Raleigh, NC 27606, USA \\ ${ }^{3} U S D A / A R S / C P M R U$, Tifton, GA 31794, USA
}

\section{TABLE OF CONTENTS}

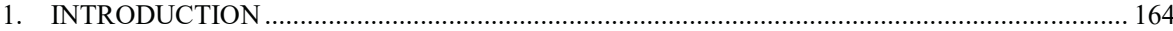

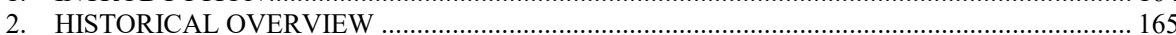

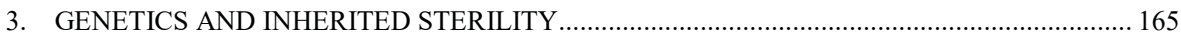

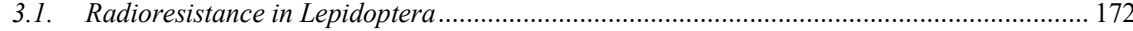

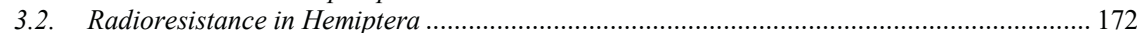

3.3. Radiation-Induced Sterility in Parental $\left(P_{1}\right)$ Generation ............................................... 173

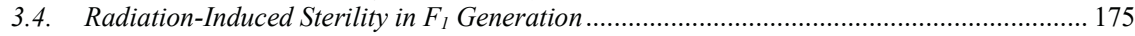

3.5. Sex-Specific Differences in Inherited Sterility ................................................................... 176

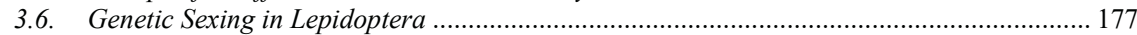

4. ADVANTAGES OF INHERITED STERILITY VERSUS FULL STERILITY ......................... 179

5. POTENTIAL FOR INHERITED STERILITY TO SUPPRESS PEST POPULATIONS ............... 180

6. COMPATIBILITY OF INHERITED STERILITY WITH OTHER PEST CONTROL

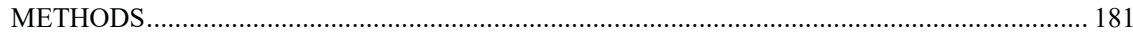

7. POPULATION MODELS COMBINING THE EFFECTS OF $F_{1}$ STERILITY WITH

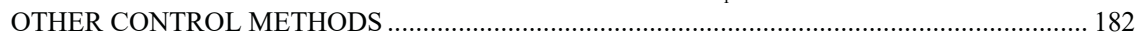

8. INHERITED STERILITY IN COMBINATION WITH BIOLOGICAL CONTROL .................... 182

9. ADDITIONAL APPLICATIONS OF F 1 STERILITY FOR RESEARCH AND

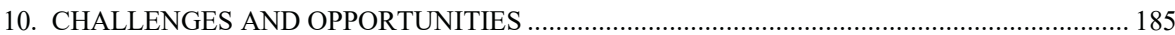

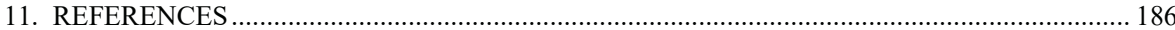

Pages 163-200

V. A. Dyck, J. Hendrichs and A. S. Robinson (eds.), Sterile Insect Technique. Principles and Practice in Area-Wide Integrated Pest Management. Second Edition.

Published with the permission of (C) 2021, US Government. CRC Press, Boca Raton, Florida, USA. 


\section{SUMMARY}

The unique genetic phenomena responsible for inherited sterility (IS) in Lepidoptera and some other arthropods, as compared with full sterility, provide advantages for pest control. Lepidopteran females are usually more sensitive to radiation than males of the same species. This allows the radiation dose to be adjusted to suit programme requirements. When partially sterile males mate with wild females, the radiation-induced deleterious effects are inherited by the $F_{1}$ generation. As a result, egg hatch is reduced and the resulting offspring are both highly sterile and predominately male. Compared with the high radiation required to achieve full sterility in Lepidoptera, the lower dose of radiation used to induce $\mathrm{F}_{1}$ sterility increases the quality and competitiveness of the released insects as measured by improved dispersal after release, increased mating ability, and superior sperm competition. $F_{1}$ sterile progeny produced in the field enhance the efficacy of released partially sterile males, and improve compatibility with other pest control strategies. In addition, $F_{1}$ sterile progeny can be used to increase the production of natural enemies, and to study the potential host and geographical ranges of exotic lepidopteran pests.

\section{INTRODUCTION}

Lepidopteran species are among the most destructive pests of annual and perennial crops, forests, and stored products throughout the world. Following the successful area-wide integrated pest management (AW-IPM) programme, integrating the sterile insect technique (SIT), against the screwworm fly Cochliomyia hominivorax (Coquerel) (Bushland 1971), studies were conducted on the possibility of suppressing lepidopteran pest populations through the release of radiation-sterilized moths. However, because Lepidoptera are radioresistant compared with most other insects (LaChance et al. 1967; Bakri et al., this volume), a dose required to achieve full sterility is so high that it reduces the ability of sterile moths to compete with wild moths. To increase the competitiveness of irradiated Lepidoptera, Proverbs (1962) investigated the effects of substerilizing doses of radiation on the codling moth Cydia pomonella (L). He noted that male moths treated with substerilizing doses and then mated to fertile females produced reduced numbers of $F_{1}$ progeny, the majority of which were males with very low fertility. This discovery prompted numerous investigations in many lepidopteran pests. North (1975) and LaChance (1985) provide thorough reviews of the early investigations on inherited sterility (IS), and discuss potential advantages of using IS in suppressing pest populations and its possible genetic basis.

IS is also referred to as inherited partial sterility, partial sterility, delayed sterility, semi-sterility and $F_{1}$ sterility (Vreysen et al. 2016). Although it is difficult to find a satisfactory definition for IS, LaChance (1985) described several attributes that are common to IS in Lepidoptera: $\mathrm{F}_{1}$ male and female offspring are more sterile than the irradiated parental $\left(\mathrm{P}_{1}\right)$ generation, and more $\mathrm{F}_{1}$ male progeny than female progeny are produced. Other attributes may include longer developmental time and reduced sperm quality in the $F_{1}$ generation. Radiation-induced deleterious effects can be inherited for several generations; however, the majority of the inherited deleterious effects are expressed in the $\mathrm{F}_{1}$ generation. 


\section{HISTORICAL OVERVIEW}

IS was first reported during studies in the Soviet Union of radiation-induced genetic anomalies in the silkworm Bombyx mori (L.) (Astaurov and Frolova 1935). A few years later Ostriakova-Varshaver (1937) reported IS in the greater wax moth Galleria melonella (L.). In North America, Proverbs (1962) was the first to describe IS in the codling moth. Within the order Hemiptera, LaChance and Degrugillier (1969) reported IS while conducting genetic studies on the large milkweed bug Oncopeltus fasciatus (Dallas), and Delrio and Cavalloro (1975) and Maudlin (1976) documented IS in Gonocerus acuteangulatus (Goeze), a coreid pest of hazelnuts, and in Rhodnius prolixus (Stål), a reduviid vector of Chagas' disease, respectively. IS has also been reported in mites of the family Tetranychidae (Henneberry 1964). Although Curtis (1969) and Curtis et al. (1973) found low levels of sterility (5-15\%) in the $F_{1}$ generation of irradiated tsetse flies (Diptera: Glossinidae), this level of sterility was less than that found in the irradiated parents, and other attributes common to IS in Lepidoptera were not demonstrated in these insects.

The genetic basis for IS has been reviewed and discussed by many authors (Bauer 1967; LaChance 1967, 1974, 1985; LaChance et al. 1970; North and Holt 1970; North 1975; LaChance and Graham 1984; Anisimov et al. 1989; Marec et al. 1999; Tothová and Marec 2001). In this chapter, emphasis will be given to the more recent research findings in the order Lepidoptera. Also the use of genetic sexing, together with IS for the suppression of lepidopteran populations, will be discussed briefly. The advantages of IS as compared with full sterility, the potential for IS to suppress pest populations, and the compatibility of IS with other pest control methods, particularly with biological control, are also discussed. Table 1 provides a comprehensive list of arthropod species where IS has been documented, and includes key references that deal with radiation biology and field studies.

\section{GENETICS AND INHERITED STERILITY}

No comprehensive review of lepidopteran genetics has been published in the last 45 years. Robinson (1971) provided useful information on formal genetics (including karyology) for many species in this large order. Additional information can be extracted from published research on three economically important species: the silkworm (Tazima 1964; Goldsmith 1995; Fujii et al. 1998; Nagaraju 2000), the Mediterranean flour moth Ephestia kuehniella (Zeller) (Caspari and Gottlieb 1975; Leibenguth 1986), and the pink bollworm Pectinophora gossypiella (Saunders) (LaChance and Ruud 1980; Bartlett 1989; Bartlett and Del Fosse 1991). Recent advances in the molecular biology and genetics of established and emerging lepidopteran models have been summarized in Goldsmith and Marec (2010).

The lepidopteran genome exhibits a number of peculiarities that distinguishes it from the genomes of other insect orders, except perhaps from that of the closely related order Trichoptera. Chromosomes in Lepidoptera are usually small, numerous, and possess few differentiating features. Most species are reported to have haploid numbers close to $30(\mathrm{n}=28-32) ; \mathrm{n}=31$ appears to be the ancestral number (Ahola et al. 2014). However, karyological studies have identified species 
with lower or higher chromosome numbers that are probably the result of chromosome fusion or fission (Suomalainen 1969a; Robinson 1971; reviewed in Marec et al. 2010). Lepidopteran chromosomes are usually spherical and uniform in shape, and consequently not much is known about their morphology, kinetic organization and behaviour during mitotic and meiotic cell division. Lepidopteran chromosomes lack distinct primary constrictions (centromeres) and, as a result, sister chromatids separate by parallel disjunction during mitotic metaphase. Many researchers have concluded that these genomic peculiarities are an indication that lepidopteran chromosomes are holokinetic (Murakami and Imai 1974). However, ultrastructure studies suggest that lepidopteran chromosomes are intermediate between holokinetic and monocentric (Wolf 1996). Nevertheless, a recent functional analysis of the silkworm kinetochore supports the holokinetic structure, although different from the other groups of organisms with holokinetic chromosomes (Mon et al. 2014).

Two other groups of arthropods have shown IS, mites (Acari) and Hemiptera; both possess holokinetic chromosomes and are radioresistant (Brown and NelsonRees 1961; Hughes-Schrader and Schrader 1961; LaChance and Degrugillier 1969; Wrensch et al. 1994). Gassner and Klemetson (1974) showed that the kinetochore (centromere) in the large milkweed bug covers more than $70 \%$ of the chromosomal surface. Gonzales-Garcia et al. (1996) provided indirect evidence of the holokinetic nature of hemipteran chromosomes while working with Graphosoma italicum (Muller) (Pentatomidae). Nonetheless, Wolf (1996) suggests that further investigation is needed to verify the holokinetic nature of hemipteran chromosomes.

The sex chromosomes of Lepidoptera are of the WZ type, in which females are heterogametic (WZ) and males homogametic (ZZ). Lepidopteran species, where sex chromosomes have been identified, show a typical $\$ \mathrm{WZ} / \widehat{ } \mathrm{ZZ}$ system, or variants such as $\mathrm{Z} / \mathrm{ZZ}, \mathrm{W}_{1} \mathrm{~W}_{2} \mathrm{Z} / \mathrm{ZZ}$ or $\mathrm{WZ}_{1} \mathrm{Z}_{2} / \mathrm{Z}_{1} \mathrm{Z}_{1} \mathrm{Z}_{2} \mathrm{Z}_{2}$ (Suomalainen $1969 \mathrm{~b}$; Robinson 1971; Nilsson et al. 1988; Traut and Marec 1997; Rishi et al. 1999; reviewed in Traut et al. 2007 and Marec et al. 2010). Male chromosomes display a normal sequence of meiotic events. In contrast, female chromosomes undergo normal meiosis until they approach the pachytene stage (Fig. 1), when they pair by means of synaptonemal complexes to form bivalents, and synaptonemal complexes become visible (Marec 1996). From this point onwards, female meiosis proceeds without meiotic recombination, and is achiasmate (Traut 1977; Nokkala 1987). The synaptonemal complexes in the female transform into elimination chromatin that later detaches from the bivalents and persists during chromosome segregation in the metaphase plate (Rasmussen 1977). The female W and Z chromosomes, although often non-homologous and of different size, pair completely during meiosis and form a regular bivalent.

Another peculiarity of the lepidopteran genome is the presence of one or more heterochromatic bodies in female somatic cells during interphase. This female specific heterochromatin (also known as $\mathrm{W}$ - or sex-chromatin) is derived from the W chromosome. Since sex chromatin is easily identified in interphase nuclei and is especially visible in highly polyploid somatic cells, it can be used as a marker to determine the sex of embryos and larvae and also to identify sex chromosome aberrations in mutagenesis screens (Traut and Marec 1996; Fuková et al. 2009). 
Table 1. Arthropod species, including key references of radiation biology and field studies, in which inherited sterility (IS) has been documented

\begin{tabular}{|c|c|c|}
\hline \multirow{2}{*}{$\begin{array}{l}\text { Family, species, and } \\
\text { common name }\end{array}$} & \multicolumn{2}{|c|}{ Key references } \\
\hline & Radiation biology & Field studies \\
\hline & Arachnida-Acari & \\
\hline $\begin{array}{l}\text { Tetranychidae } \\
\text { Tetranychus urticae Koch } \\
\text { twospotted spider mite }\end{array}$ & Henneberry 1964 & \\
\hline & Insecta-Hemiptera & \\
\hline $\begin{array}{l}\text { Coreidae } \\
\text { Gonocerus acuteangulatus } \\
\text { (Goeze) } \\
\quad \text { box bug }\end{array}$ & Delrio and Cavalloro 1975 & \\
\hline $\begin{array}{l}\text { Lygaeidae } \\
\text { Oncopeltus fasciatus (Dallas) } \\
\text { large milkweed bug }\end{array}$ & $\begin{array}{l}\text { LaChance and Degrugillier } \\
1969 \\
\text { LaChance et al. } 1970\end{array}$ & \\
\hline \multicolumn{3}{|l|}{ Reduviidae } \\
\hline & Insecta - Lepidoptera & \\
\hline $\begin{array}{l}\text { Bombycidae } \\
\text { Bombyx mori (L.) } \\
\text { silkworm }\end{array}$ & $\begin{array}{l}\text { Sugai and Mirumachi } 1973 \\
\text { Murakami } 1976\end{array}$ & \\
\hline $\begin{array}{l}\text { Crambidae } \\
\text { Crocidolomia binotalis } \\
\text { (Zeller) } \\
\text { cabbage webworm }\end{array}$ & $\begin{array}{l}\text { Sutrisno Apu and Hoedaya } \\
1993\end{array}$ & $\begin{array}{l}\text { Sutrisno Apu and Hoedaya } \\
1993 \\
\text { Sutrisno Apu } 2001\end{array}$ \\
\hline $\begin{array}{l}\text { Diatraea saccharalis (F.) } \\
\text { sugarcane borer }\end{array}$ & $\begin{array}{l}\text { Walker and Quintana 1968a, b } \\
\text { Walker et al. } 1971 \\
\text { Sanford 1976; } 1977 \\
\text { García and González } 1993 \\
\text { González and García } 1993\end{array}$ & \\
\hline $\begin{array}{l}\text { Ostrinia furnacalis (Guenée) } \\
\text { Asian corn borer }\end{array}$ & $\begin{array}{l}\text { Li et al. } 1988 \\
\text { Zhang et al. } 1993 \\
\text { Wang et al. } 2001\end{array}$ & Wang et al. 2001 \\
\hline $\begin{array}{l}\text { Ostrinia nubilalis (Hübner) } \\
\text { European corn borer }\end{array}$ & $\begin{array}{l}\text { Shang and Lo } 1980 \\
\text { Nabors and Pless } 1981 \\
\text { Rosca and Barbulescu } 1990 \\
\text { Barbulescu and Rosca } 1993 \\
\text { Rosca and Barbulescu } 1993\end{array}$ & $\begin{array}{l}\text { Barbulescu and Rosca } 1993 \\
\text { Rosca and Barbulescu } 1993\end{array}$ \\
\hline
\end{tabular}


Table 1. Continued

\begin{tabular}{|c|c|c|}
\hline \multirow{2}{*}{$\begin{array}{l}\text { Family, species, and } \\
\text { common name }\end{array}$} & \multicolumn{2}{|c|}{ Key references } \\
\hline & Radiation biology & Field studies \\
\hline $\begin{array}{l}\text { Gelechiidae } \\
\text { Pectinophora gossypiella } \\
\text { (Saunders) } \\
\text { pink bollworm }\end{array}$ & $\begin{array}{l}\text { Cheng and North } 1972 \\
\text { Graham et al. } 1972 \\
\text { LaChance et al. 1973; } 1976 \\
\text { Henneberry and Clayton } 1981 \\
\text { Miller et al. } 1984 \\
\text { Qureshi et al. 1993a }\end{array}$ & $\begin{array}{l}\text { Bariola et al. } 1973 \\
\text { Flint et al. } 1974 \\
\text { Qureshi et al. } 1993 \mathrm{~b}\end{array}$ \\
\hline $\begin{array}{l}\text { Phthorimaea operculella } \\
\text { (Zeller) } \\
\text { potato tuberworm }\end{array}$ & $\begin{array}{l}\text { Makee and Saour } 1997 \\
\text { Makee et al. } 2007\end{array}$ & \\
\hline $\begin{array}{l}\text { Sitotroga cerealella } \\
\text { (Olivier) } \\
\quad \text { Angoumois grain moth }\end{array}$ & Cogburn et al. 1966 & \\
\hline $\begin{array}{l}\text { Tuta absoluta (Meyrick) } \\
\text { tomato leafminer }\end{array}$ & $\begin{array}{l}\text { Cagnotti et al. } 2012 \\
\text { Carabajal Paladino et al. } 2016\end{array}$ & Cagnotti et al. 2016 \\
\hline $\begin{array}{l}\text { Gracillariidae } \\
\text { Conopomorpha sinensis } \\
\text { Bradley } \\
\text { litchi stem-end borer }\end{array}$ & $\begin{array}{l}\text { Fu et al. } 2016 \\
\text { Zhang et al. } 2016\end{array}$ & $\begin{array}{l}\text { Fu et al. } 2016 \\
\text { Zhang et al. } 2016\end{array}$ \\
\hline $\begin{array}{l}\text { Lymantriidae } \\
\text { Lymantria dispar (L.) } \\
\text { gypsy moth }\end{array}$ & $\begin{array}{l}\text { Mastro et al. } 1989 \\
\text { Proshold et al. } 1993 \\
\text { Proshold } 1995\end{array}$ & $\begin{array}{l}\text { Maksimovic } 1972 \\
\text { Mastro et al. } 1989 \\
\text { Mastro } 1993 \\
\text { Strom et al. } 1996\end{array}$ \\
\hline $\begin{array}{l}\text { Teia anartoides Walker } \\
\text { painted apple moth }\end{array}$ & $\begin{array}{l}\text { Suckling et al. } 2002 \\
\text { Wee et al. } 2005\end{array}$ & Suckling et al. 2002 \\
\hline $\begin{array}{l}\text { Noctuidae } \\
\text { Agrotis ipsilon (Hufnagel) } \\
\text { black cutworm }\end{array}$ & Elnagar et al. 1984 & \\
\hline $\begin{array}{l}\text { Helicoverpa armigera } \\
\text { (Hübner) } \\
\text { cotton bollworm }\end{array}$ & $\begin{array}{l}\text { Saifutdinov } 1989 \\
\text { Ocampo } 2001 \\
\text { Sachdev et al. } 2014\end{array}$ & \\
\hline $\begin{array}{l}\text { Helicoverpa zea (Boddie) } \\
\text { corn earworm } \\
\text { bollworm } \\
\text { tomato fruitworm }\end{array}$ & $\begin{array}{l}\text { Carpenter et al. 1987c } \\
\text { Carpenter and Gross } 1989 \\
\text { Carpenter 1991; } 1992 \\
\text { Carpenter and Wiseman 1992a } \\
\text { Hamm and Carpenter } 1997\end{array}$ & $\begin{array}{l}\text { North and Snow } 1978 \\
\text { Carpenter et al. 1987a, b; } 1989 \\
\text { Carpenter and Gross } 1993 \\
\text { Mannion et al. 1994; } 1995\end{array}$ \\
\hline $\begin{array}{l}\text { Heliothis virescens }(\mathrm{F} .) \\
\text { tobacco budworm }\end{array}$ & $\begin{array}{l}\text { Proshold and Bartell 1970; } \\
\text { 1972a, b; } 1973 \\
\text { Guerra and Garcia } 1976\end{array}$ & North and Snow 1978 \\
\hline
\end{tabular}


Table 1. Continued

\begin{tabular}{|c|c|c|}
\hline \multirow{2}{*}{$\begin{array}{l}\text { Family, species, and } \\
\text { common name }\end{array}$} & \multicolumn{2}{|c|}{ Key references } \\
\hline & Radiation biology & Field studies \\
\hline $\begin{array}{l}\text { Noctuidae } \\
\text { Spodoptera exigua (Hübner) } \\
\text { beet armyworm }\end{array}$ & $\begin{array}{l}\text { Debolt } 1973 \\
\text { Carpenter et al. } 1996\end{array}$ & \\
\hline $\begin{array}{l}\text { Spodoptera frugiperda } \\
\text { (J. E. Smith) } \\
\text { fall armyworm }\end{array}$ & $\begin{array}{l}\text { Carpenter et al. 1983; 1986; } \\
1997 \\
\text { Carpenter and Young } 1991 \\
\text { Arthur et al. } 1993 \\
\text { Hamm and Carpenter } 1997\end{array}$ & $\begin{array}{l}\text { Carpenter et al. } 1985 \\
\text { Carpenter and Wiseman 1992b }\end{array}$ \\
\hline $\begin{array}{l}\text { Spodoptera littoralis } \\
\text { Boisduval } \\
\text { Egyptian cotton leafworm }\end{array}$ & $\begin{array}{l}\text { Wakid and Hayo } 1974 \\
\text { Sallam and Ibrahim } 1993\end{array}$ & Sallam and Ibrahim 1993 \\
\hline $\begin{array}{l}\text { Spodoptera litura }(\mathrm{F} .) \\
\text { Oriental leafworm } \\
\text { taro caterpillar }\end{array}$ & $\begin{array}{l}\text { Seth and Sehgal } 1993 \\
\text { Sutrisno Apu et al. } 1993 \\
\text { Seth and Sharma } 2001 \\
\text { Seth et al. 2016a, b }\end{array}$ & Seth et al. $2016 b$ \\
\hline $\begin{array}{l}\text { Trichoplusia ni (Hübner) } \\
\text { cabbage looper }\end{array}$ & $\begin{array}{l}\text { North and Holt 1968; } 1969 \\
\text { Ercelik and Holt 1972 } \\
\text { Karpenko and North } 1973\end{array}$ & Toba et al. 1972 \\
\hline $\begin{array}{l}\text { Pieridae } \\
\text { Pieris brassicae (L.) } \\
\text { the large white }\end{array}$ & Bauer 1967 & \\
\hline $\begin{array}{l}\text { Plutellidae } \\
\text { Plutella xylostella (L.) } \\
\text { diamondback moth }\end{array}$ & $\begin{array}{l}\text { Omar and Mansor } 1993 \\
\text { Sutrisno Apu and Hoedaya } \\
1993 \\
\text { Sutrisno Apu et al. } 1993 \\
\text { Nguyen Thi and Nguyen Thanh } \\
2001\end{array}$ & $\begin{array}{l}\text { Sutrisno Apu and Hoedaya } \\
1993 \\
\text { Okine et al. } 1998 \\
\text { Mitchell et al. } 1999 \\
\text { Nguyen Thi and Nguyen Thanh } \\
2001 \\
\text { Sutrisno Apu } 2001\end{array}$ \\
\hline $\begin{array}{l}\text { Pyralidae } \\
\text { Amyelois transitella (Walker) } \\
\text { navel orangeworm }\end{array}$ & $\begin{array}{l}\text { Husseiny and Madsen } 1964 \\
\text { Light et al. } 2015\end{array}$ & \\
\hline $\begin{array}{l}\text { Cactoblastis cactorum (Berg) } \\
\text { cactus moth }\end{array}$ & $\begin{array}{l}\text { Carpenter et al. 2001b } \\
\text { López-Martínez et al. } 2016\end{array}$ & $\begin{array}{l}\text { Bloem et al. 2003a } \\
\text { Hight et al. } 2005\end{array}$ \\
\hline $\begin{array}{l}\text { Cadra cautella (Walker) } \\
\text { almond moth }\end{array}$ & $\begin{array}{l}\text { Ahmed et al. } 1971 \\
\text { Gonnen and Calderón } 1971 \\
\text { Brower 1980; } 1982 \\
\text { Al-Taweel et al. } 1990 \\
\text { Makee } 1993\end{array}$ & \\
\hline
\end{tabular}


Table 1. Continued

\begin{tabular}{|c|c|c|}
\hline \multirow{2}{*}{$\begin{array}{l}\text { Family, species, and } \\
\text { common name }\end{array}$} & \multicolumn{2}{|c|}{ Key references } \\
\hline & Radiation biology & Field studies \\
\hline $\begin{array}{l}\text { Pyralidae } \\
\text { Corcyra cephalonica } \\
\text { (Stainton) } \\
\text { rice moth }\end{array}$ & Chand and Sehgal 1982 & \\
\hline $\begin{array}{l}\text { Eldana saccharina Walker } \\
\text { African sugarcane stalk borer }\end{array}$ & $\begin{array}{l}\text { Mudavanhu et al. } 2016 \\
\text { Walton and Conlong } 2016\end{array}$ & \\
\hline $\begin{array}{l}\text { Ephestia kuehniella Zeller } \\
\text { Mediterranean flour moth }\end{array}$ & $\begin{array}{l}\text { Riemann } 1973 \\
\text { Marec et al. } 1999 \\
\text { Tothová and Marec } 2001 \\
\text { Ayvaz and Tunçbilek } 2006 \\
\text { Ayvaz et al. } 2007\end{array}$ & \\
\hline $\begin{array}{l}\text { Galleria mellonella }(\mathrm{L} .) \\
\text { greater wax moth }\end{array}$ & $\begin{array}{l}\text { Nielsen } 1971 \\
\text { Nielsen and Lambremont } 1976 \\
\text { Nielsen and Brister } 1980\end{array}$ & \\
\hline $\begin{array}{l}\text { Plodia interpunctella } \\
\text { (Hübner) } \\
\text { Indian meal moth }\end{array}$ & $\begin{array}{l}\text { Cogburn et al. } 1966 \\
\text { Ashrafi et al. } 1972 \\
\text { Ashrafi and Roppel } 1973 \\
\text { Brower 1976; 1979; } 1981 \\
\text { Ayvaz et al. } 2008\end{array}$ & \\
\hline $\begin{array}{l}\text { Sphingidae } \\
\text { Manduca sexta }(\mathrm{L} .) \\
\text { tobacco hornworm }\end{array}$ & Seth and Reynolds 1993 & \\
\hline $\begin{array}{l}\text { Tortricidae } \\
\text { Cydia pomonella }(\mathrm{L} .) \\
\text { codling moth }\end{array}$ & $\begin{array}{l}\text { Proverbs } 1962 \\
\text { Fossati et al. } 1971 \\
\text { Charmillot et al. } 1973 \\
\text { Pristavko et al. } 1973 \\
\text { White } 1975 \\
\text { Anisimov et al. } 1989 \\
\text { Bloem et al. 1999a }\end{array}$ & $\begin{array}{l}\text { Charmillot et al. } 1973 \\
\text { Charmillot } 1977 \\
\text { Proverbs et al. } 1978 \\
\text { Bloem et al. } 1999 \text { b; } 2001\end{array}$ \\
\hline $\begin{array}{l}\text { Epiphyas postvittana (Walker) } \\
\text { light brown apple moth }\end{array}$ & Soopaya et al. 2011 & Woods et al. 2016 \\
\hline $\begin{array}{l}\text { Grapholita molesta (Busck) } \\
\text { oriental fruit moth }\end{array}$ & Genchev 2001 & Genchev 2001 \\
\hline $\begin{array}{l}\text { Lobesia botrana (Denis \& } \\
\text { Schiffermüller) } \\
\text { European grapevine moth }\end{array}$ & Steinitz et al. 2015 & Saour 2016 \\
\hline $\begin{array}{l}\text { Thaumatotibia leucotreta } \\
\text { (Meyrick) } \\
\text { false codling moth }\end{array}$ & $\begin{array}{l}\text { Schwartz } 1978 \\
\text { Bloem et al. } 2003 \mathrm{~b}\end{array}$ & \\
\hline
\end{tabular}



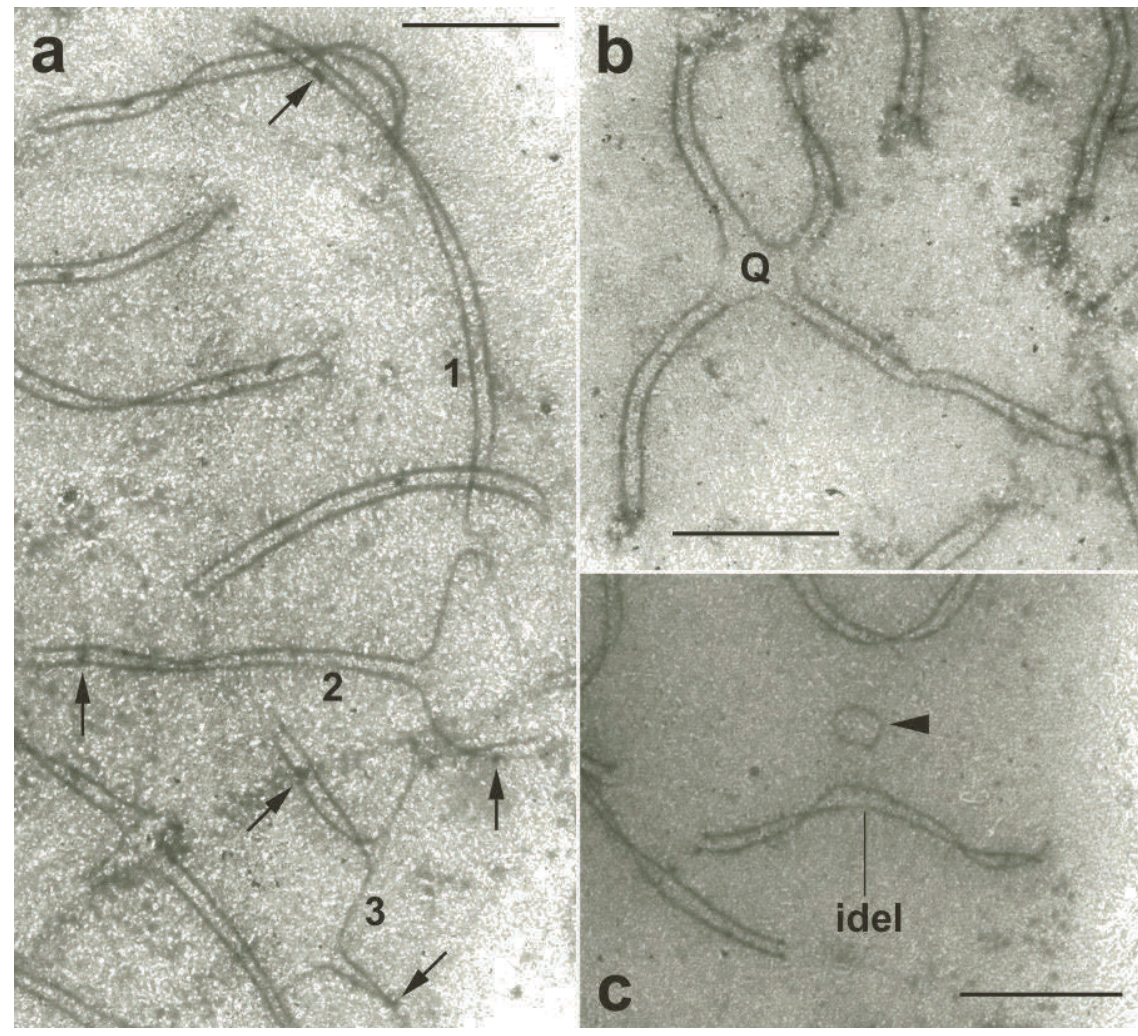

Figure 1. Examples of pachytene configurations in aberrant chromosomes of Ephestia kuehniella in microspread spermatocytes of $F_{1}$ males after the parental male was irradiated with $150 \mathrm{~Gy}$. a: Multiple chain translocation that involves 7 lateral elements, each representing the protein axis of one chromosome, where 1-3 represent structurally normal chromosomes inherited from the untreated female parent; arrows indicate recombination nodules; $b$ : Quadrivalent (Q) typical in reciprocal translocations; $c$ : Ring fragment (arrow) plus a bivalent with one shorter lateral element (idel) that indicates interstitial deletion. All are electron microscope (EM) micrographs stained with phosphotungstic acid. Scale $=2 \mu \mathrm{m}$.

Lepidopteran males undergo two distinct modes of spermatogenesis/meiosis that result in the production of two different types of sperm (Wolf 1994; Friedländer et al. 2005): the larger, nucleate and fertile eupyrene sperm, and the smaller, anucleate and non-fertile apyrene sperm. Apyrene sperm are more abundant and contain less mitochondrial material (Kawamura et al. 1998), while eupyrene sperm are less abundant and typically comprise $10-15 \%$ of the total sperm transferred to a female during mating (Gage and Cook 1994; Cook and Wedell 1996). The role of apyrene sperm is not fully understood, although it has been suggested that they aid the transfer of eupyrene sperm to the female (Cook and Wedell 1996), have a nutritive 
function (Friedländer 1997), or may be involved in sperm competition. The latter function was studied in Pieris napi (L.), where the presence of apyrene sperm was shown to delay female remating (Cook and Wedell 1999).

\subsection{Radioresistance in Lepidoptera}

A high resistance to the effects of ionizing radiation is a characteristic feature of moths and butterflies (LaChance 1985). Cultured lepidopteran cells are 50-100 times more resistant to radiation-induced death than similarly cultured mammalian cells. In contrast dipteran cells are only three to nine times more resistant than mammalian cells (Koval 1996; Chandna et al. 2004). Results of recent studies of a Sf9 cell line, originally derived from Spodoptera frugiperda, suggest that several intracellular mechanisms, such as an efficient antioxidant defence and a high activity of histone deacetylases, contribute to the radioresistance of lepidopteran cells (Suman et al. 2015; Sharma et al. 2016). This high radioresistance in Lepidoptera also applies to germ cells, and in particular to mature sperm. As a consequence very high doses of radiation are required to fully sterilize lepidopteran males (LaChance and Graham 1984).

LaChance and Graham (1984) and Koval (1996) suggested that possible molecular mechanisms responsible for the high radioresistance in Lepidoptera might include an inducible cell recovery system and a DNA repair process. Even though lepidopteran chromosomes are not truly holokinetic, a significant role in their radioresistance can be attributed to their holokinetic "nature" (as first suggested by LaChance et al. 1967) and to the fate of the radiation-induced chromosome fragments during mitotic cell cycles as explained below (Tothová and Marec 2001). Lepidopteran chromosomes possess a localized kinetochore plate to which the spindle microtubules attach during cell division (Gassner and Klemetson 1974; Traut 1986; Wolf and Traut 1991; Wolf et al. 1997). The kinetochore plates are large and cover a significant portion of the chromosome length (Wolf 1996), ensuring that most radiation-induced breaks will not lead to the loss of chromosome fragments as is typical in species with monocentric chromosomes. In species with large kinetochore plates, the fragments may persist for a number of mitotic cell divisions, and can even be transmitted through germ cells to the next generation (Marec and Traut 1993a; Marec et al. 2001). The plates also reduce the risk of lethality caused by the formation of dicentric chromosomes, acentric fragments, and other unstable aberrations (Tothová and Marec 2001) (Fig. 2).

\subsection{Radioresistance in Hemiptera}

A difference in radiosensitivity between males and females has also been documented in several hemipterans including species of economically important leafhoppers (Shipp et al. 1966; Ameresekere and Georghiou 1971) and mealybugs (Brown and Nelson-Rees 1961). However, LaChance and Degrugillier (1969) were the first to document IS in the order Hemiptera when they induced chromosomal fragments and translocations in the large milkweed bug. These authors demonstrated 
that the induced fragments were both mitotically and meiotically stable, and could be transmitted through three generations of outcrosses to normal females.
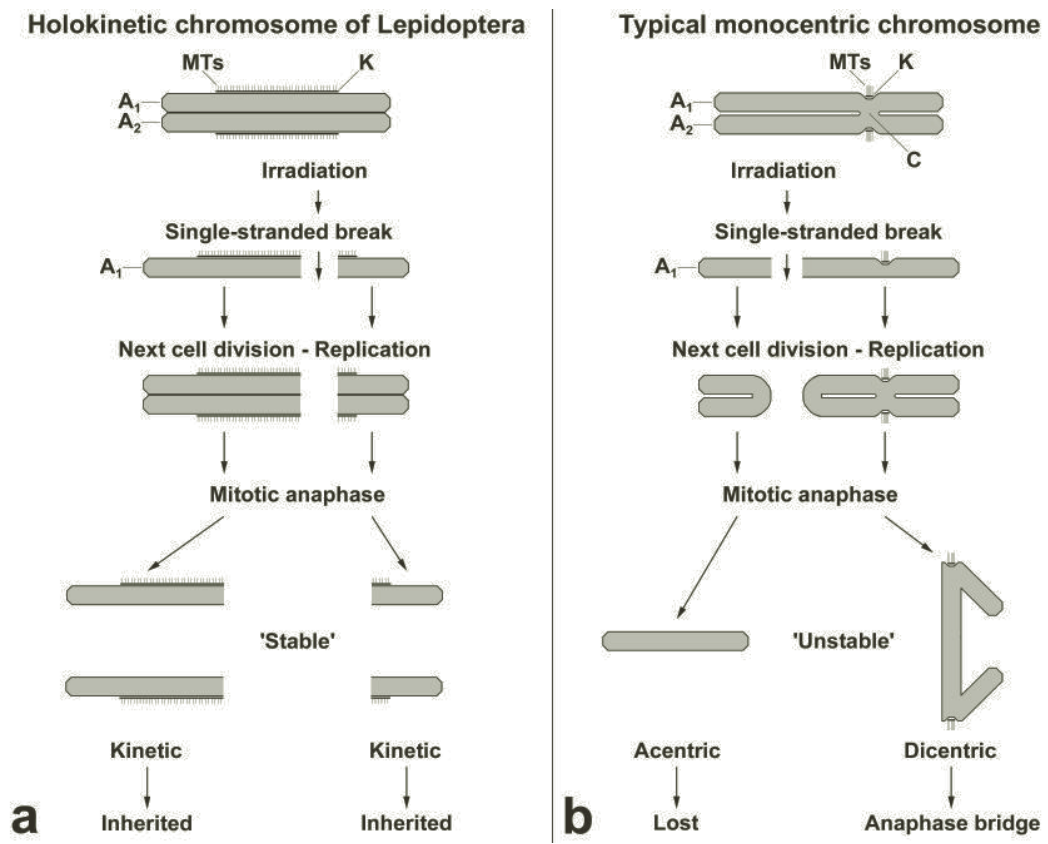

Figure 2. Kinetic structure of lepidopteran chromosomes during mitotic metaphase, and consequences of chromosome breakage; a: Holocentric chromosome with two sister chromatids ( $A_{1}$ and $A_{2}$ ), each with a kinetochore plate $(K)$ covering about $50 \%$ of the chromosome surface; spindle microtubules (MTs) are attached to the kinetochore; $\boldsymbol{b}$ : Typical monocentric chromosome, where sister chromatids are joined by the centromere $(C)$; the kinetochore is localized on the surface of the centromere.

\subsection{Radiation-Induced Sterility in Parental $\left(P_{l}\right)$ Generation}

Radiation-induced sterility is generally a consequence of dominant lethal mutations (DLMs) that result in the death of the zygote or the embryo. The chromosomal damage responsible for DLMs is characterized by the formation of anaphase chromosome bridges, chromosome fragments and other abnormalities in the dividing nuclei. In most insects DLMs are expressed during early embryogenesis (LaChance 1967). In Lepidoptera, however, the frequency of DLMs is much lower than in other insects and the majority are expressed very late in embryonic development (LaChance 1974; Berg and LaChance 1976). Furthermore, no chromosomal bridges, indicating the presence of dicentric chromosomes, are evident during embryonic development in Lepidoptera (LaChance and Graham 1984) and Hemiptera studied thus far (LaChance et al. 1970; Maudlin 1976). 
For males of four insect species, LaChance and Graham (1984) constructed dose-response curves for the induction of DLMs in mature sperm. The species exhibited a wide range of radiosensitivity, with Hemiptera showing intermediate and Lepidoptera high radioresistance. When analysed mathematically, the dose-response curves approximated an S-shape (LaChance and Graham 1984; Marec et al. 1999). For highly radioresistant Lepidoptera, the curves approximated those expected for 8-16-hit kinetics while in Hemiptera the curve exhibited 4-hit kinetics. These data suggest that multiple chromosome rearrangements must be induced in lepidopteran males to be manifested as DLMs, explaining why lepidopteran males require very high radiation doses (350-500 Gy) to be fully sterilized.

Radiation-induced sterility in lepidopteran males may also have other causes. Anisimov et al. (1989) observed a dose-dependent increase in the number of matings that produced no eggs, or the number of females that laid only unembryonated eggs, following mating with irradiated male codling moths. A significant proportion of unembryonated eggs (that might represent unfertilized eggs and/or eggs with early embryonic mortality) were also observed after treated males were mated to females of Manduca sexta (L.) (Seth and Reynolds 1993), E. kuehniella (Marec et al. 1999), and Spodoptera litura (F.) (Seth and Sharma 2001). Furthermore, Koudelová and Cook (2001) demonstrated with E. kuehniella that the volume of sperm transferred during copula decreased, and mating times increased, as the dose increased. Irradiated males of Tuta absoluta (Meyrick) produced a significantly higher portion of deformed eupyrene sperm bundles than untreated males (Carabajal Paladino et al. 2016). Taken together, the above data suggest that an important component of male sterility can be due to physiological disruptions during copulation, including the inability to copulate and abnormal sperm transfer.

Lepidopteran females are considerably more radiosensitive than males. In a number of species, a dose of $100 \mathrm{~Gy}$ is sufficient to achieve almost full sterility in treated females (Anisimov et al. 1989; Marec and Mirchi 1990; Bloem et al. 1999a) (Fig. 3). It appears that this difference in radiosensitivity between males and females is related to the stage of development of the reproductive cells at the time of irradiation. Lepidoptera are usually irradiated as mature pupae or newly emerged adults. At this stage of development eupyrene spermiogenesis in the male has been completed, and the nuclei in eupyrene sperm are in interphase. In contrast, female meiosis is arrested at metaphase I in the nuclei of mature oocytes and the process does not resume until the eggs have been laid (Traut 1977). As a consequence irradiation of newly emerged females or of mature female pupae may disrupt the normal course of meiosis including chromosome segregation. Finally, various secondary detrimental effects can be expected in oocytes, which have a large amount of cytoplasm (that contains many components required for embryonic development) in comparison with the essentially cytoplasm-free sperm. Almost nothing is known about the radiosensitivity of female Hemiptera, although Delrio and Cavalloro (1975) showed that $G$. acuteangulatus females were fully sterilized at a dose of 5060 Gy. At this dose males were about $70 \%$ sterile. 


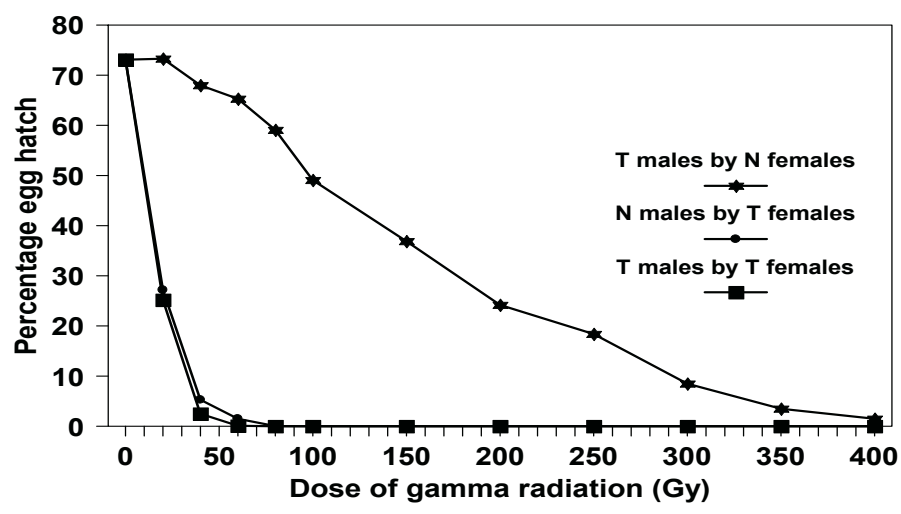

Figure 3. Percentage egg hatch obtained when codling moth adults were treated with increasing doses of gamma radiation, and either inbred or outcrossed with fertile moths. $T=$ Treated, $N=$ Non-treated. (Figure from Bloem et al. 1999a.)

\subsection{Radiation-Induced Sterility in $F_{1}$ Generation}

Cytogenetic work by Tothová and Marec (2001) showed that various types of translocations (non-reciprocal, reciprocal and multiple) are responsible for the production of genetically unbalanced gametes in $\mathrm{F}_{1}$ progeny and, as such, represent the main chromosomal mechanism of IS. In addition, they demonstrated that two types of intra-chromosomal aberration, fragmentation, and interstitial deletion increase the frequency of unbalanced gametes; however, their contribution to overall sterility appears to be less significant. The study also revealed that the predicted level of $F_{1}$ sterility, based on the observed frequency of aberrations, was much higher than the sterility observed in a previous study (Marec et al. 1999). This suggests that Lepidoptera possess a mechanism that corrects the predicted unbalanced state towards a balanced segregation of chromosomes. The authors suggested that the increased number of chiasmata might facilitate a balanced disjunction of chromosomes from translocation multivalents in $F_{1}$ males. The modified synaptonemal complex, which ensures regular disjunction of homologous chromosomes during female meiosis in Lepidoptera (Rasmussen 1977; Marec 1996), might play a similar role in $F_{1}$ females (Tothová and Marec 2001).

Several authors have documented the effects of radiation on the incidence of visible chromosomal aberrations in $\mathrm{F}_{1}$ males using light microscopy (North and Snow 1978; Saifutdinov 1989; Al-Taweel et al. 1990; Carpenter 1991; Carpenter et al. 1997; Carabajal Paladino et al. 2016).

To better understand the principle of inherited sterility, Tothová and Marec (2001) used a modified micro-spreading technique, first employed by Weith and Traut (1980), to study radiation-induced chromosome aberrations in $F_{1}$ individuals of E. kuehniella. The micro-spread chromosomes were viewed with an electron microscope and several types of aberrations were documented. In $F_{1}$ individuals from male parents treated with 100 and $150 \mathrm{~Gy}$, the overall frequency of aberrations 
varied between 4.2 and 4.8 per $F_{1}$ larva in both sexes. A significant increase in aberrations was found in $F_{1}$ males from male parents treated with 200 Gy (6.2 per male). Fragmentation and several types of translocations (non-reciprocal, reciprocal, and multiple) were the most common aberrations, while interstitial deletions and inversions were rare. Multiple translocations forming complicated configurations were found with increasing radiation dose. In males the mean number of chromosomal breaks resulting in aberrations increased linearly with dose, from 8.4 to 16.2 per nucleus. In females this value reached a maximum of 11.2 breaks per nucleus when male parents were treated with a dose of 200 Gy (Fig. 1).

\subsection{Sex-Specific Differences in Inherited Sterility}

Two consequences of radiation-induced IS are sex-specific and positively correlated with treatment dose. First, the sex ratio of the $\mathrm{F}_{1}$ generation is skewed toward males (Lepidoptera - Proverbs 1962; Hemiptera - LaChance et al. 1970) and, second, the level of IS in $F_{1}$ female progeny is lower than in $F_{1}$ males (Lepidoptera Anisimov et al. 1989; Al-Taweel et al. 1990; Seth and Reynolds 1993; Bloem et al. 1999a).

Marec et al. (1999) suggested that the sex ratio distortion in the $F_{1}$ generation in Lepidoptera occurs as a result of recessive lethal mutations induced in the $Z$ sex chromosomes of treated male parents. Since lepidopteran females are heterogametic, all female $F_{1}$ progeny will be hemizygous for $\mathrm{Z}$ and, as a consequence, any deleterious $Z$-linked mutations will result in $F_{1}$ female mortality. In contrast, the $F_{1}$ male progeny will inherit one $\mathrm{Z}$ chromosome from the treated father and the other from the mother and, as such, will be heterozygous for any Z-linked mutation.

The induction of $F_{1}$ sterility by transmitting complex chromosome translocations to the progeny of treated males was first suggested by North (1967) and North and Holt (1968) for Lepidoptera and by LaChance and Degrugillier (1969) for Hemiptera. Tothová and Marec (2001) suggested three factors that might explain the higher level of sterility found in $\mathrm{F}_{1}$ male progeny of Lepidoptera:

- The ability of $F_{1}$ males to survive even though they inherit a large number of chromosome breaks. The authors found that in $\mathrm{F}_{1}$ males of E. kuehniella, the mean frequency of chromosome breaks was positively correlated with a dosedependent increase in sterility, whereas a clear correlation was lacking for $F_{1}$ females. They suggested that this difference was due to higher mortality in $\mathrm{F}_{1}$ females that inherit a high number of breaks. Furthermore, at higher treatment doses, there is increased probability that the sex chromosome $(Z)$ will be damaged and, as a consequence, any resulting recessive lethal mutation would kill the $F_{1}$ females but not the males. Those $F_{1}$ females that survive carry a smaller number of chromosome breaks and, therefore, are more fertile than the $\mathrm{F}_{1}$ males.

- The occurrence of crossing-over during spermatogenesis. In $F_{1}$ males crossingover during spermatogenesis might increase the number of unbalanced gametes produced, but only if it occurs at the crossover point between an aberrant chromosome (that arose by two or more breaks) and its structurally normal homologue. This situation might occur when inversions and multiple 
translocations are formed. However Tothová and Marec (2001) rarely detected inversions in their study on E. kuehniella. They concluded that crossing-over contributes to the sterility in $\mathrm{F}_{1}$ males mostly through the formation of multiple translocations. Since female meiosis is achiasmate during oogenesis, this factor cannot play a role in the sterility level of $F_{1}$ females (Rasmussen 1977; Traut 1977; Nokkala 1987; Marec and Traut 1993b).

- A higher impact of radiation-induced deleterious effects on the fertility of $F_{1}$ males. Some studies have reported finding a higher number of $F_{1}$ male crosses that are fully sterile or that have resulted in the female laying a large number of unembryonated eggs, whereas most $F_{1}$ female crosses laid embryonated eggs (Anisimov et al. 1989; Marec et al. 1999). The data suggest that induced genetic changes impaired the fertilizing ability of some $F_{1}$ males while the $F_{1}$ females were not similarly affected. In addition, Koudelová and Cook (2001) reported great variability in the number of sperm that were transferred by $\mathrm{F}_{1}$ males of $E$. kuehniella. They found that, on average, the number of eupyrene sperm decreased, whereas the number of apyrene sperm increased, resulting in an abnormally high ratio of apyrene to eupyrene sperm. The ratio fluctuated between 9.5:1 for untreated males and as high as 100:1 for treated males. These results suggest that chromosomal rearrangements in $\mathrm{F}_{1}$ males may have altered the mechanisms regulating dichotomous spermiogenesis or those underlying copulation and sperm transfer.

\subsection{Genetic Sexing in Lepidoptera}

Genetic sexing has been documented in only two lepidopteran species. Strunnikov (1975) reported that genetic sexing was possible in the silkworm, B. mori. About 15 years later Marec (1990, 1991) and Marec and Mirchi (1990) were successful in constructing in E. kuehniella a balanced lethal genetic sexing strain, according to the scheme of Strunnikov (1975). This strain, called BL-2, results in males that are trans-heterozygous for two sex-linked recessive lethal mutations, $s l-2$ and $s l-15$. When BL-2 males are mated to wild-type females, the $\mathrm{F}_{1}$ generation consists almost exclusively of male progeny. The $F_{1}$ females die during embryogenesis because they inherit one of the lethal mutations from their father, i.e., females are hemizygous for $s l-2$ or $s l-15$ (Fig. 4).

BL-2 males of E. kuehniella could be released directly into nature to introduce lethal mutations into the wild population (Marec et al. 1996), or they could be maintained in the laboratory and used to generate a male-only mutant strain that could be irradiated and released into the environment (Marec et al. 1999). Marec et al. (1999) suggested that the production of male-only colonies through the use of balanced lethal strains would reduce rearing costs and enhance population suppression when used alone or in combination with $F_{1}$ sterility. Furthermore, outcrosses of balanced lethal males with wild-type females one generation before irradiation and release would improve the competitiveness of males through positive heterosis. Finally, in addition to the genetic changes induced by treating the males with gamma radiation, the released mutant males would introduce sex-linked recessive lethal mutations into the wild population that would further reduce the 
number of $F_{1}$ females produced in the field. However, this system relies on sexing two different strains and making directed crosses, and would be impractical in an operational programme.

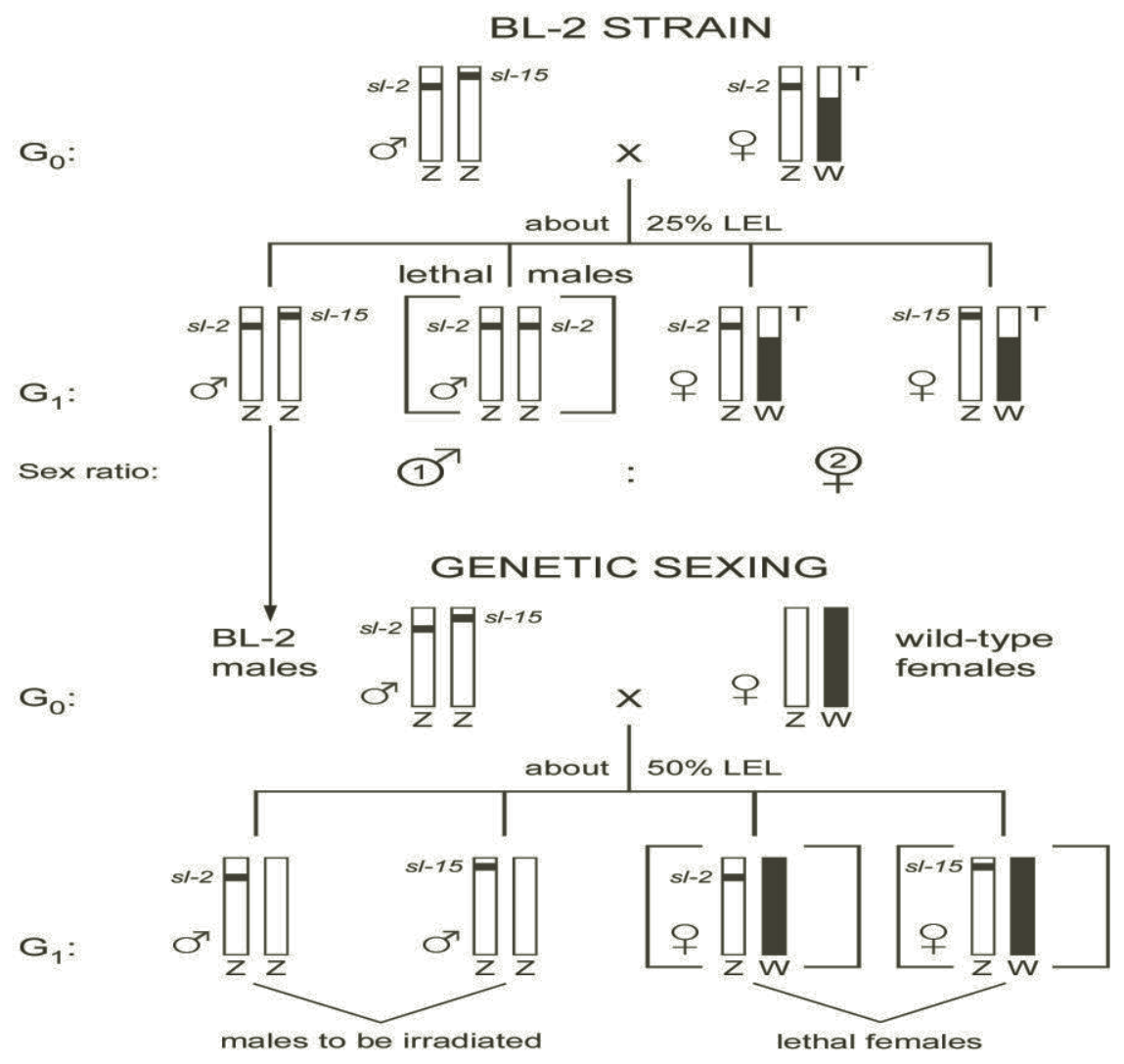

Figure 4. Genetic sexing system developed in the Mediterranean flour moth; the cross between $B L-2$ males and wild-type females produces only male progeny. $Z$ and $W$ represent the sex chromosomes; sl-2 and sl-15 are sex-linked recessive mutations. $L E L=$ late embryonic lethality (details in text).

Some significant obstacles still need to be overcome before these types of genetic sexing strain can be used against pest Lepidoptera. For example suitable markers are currently lacking for the construction of similar mutant strains in other economically important species. Also the genetic sexing system requires the massrearing of two different colonies, a wild-type strain and a balanced lethal strain, for which sex separation somehow has to be carried out under mass-rearing conditions. Finally, the mutant strain must be routinely checked to prevent the loss of its genetic structure through genetic recombination or colony contamination (Marec 1991; Franz et al., this volume). 
Discovery of the sex-determining mechanism in Lepidoptera might facilitate the development of a more convenient and sophisticated sexing system. However, little is known about sex determination in Lepidoptera and, except for the silkworm $B$. mori, the exact locations of the primary sex-determining factors are unknown (Traut and Marec 1996; Traut et al. 2007). In this species, significant progress is being made that will undoubtedly facilitate future research on lepidopteran genetics. Ohbayashi et al. (2001) found a homologue of the Drosophila doublesex ( $d s x$ ) gene in $B$. mori called Bmdsx. A sex-specific alternative splicing of the primary Bmdsx transcript, along with results of functional studies, strongly suggest that the gene controls sexual differentiation, as does the Drosophila $d s x$ gene (Suzuki 2010). In the silkworm, sex determination depends on the presence or absence of the $\mathrm{W}$ chromosome, which carries a dominant female-determining factor (Fem) (Fujii and Shimada 2007). Recently, Kiuchi et al. (2014) showed that Fem is not a proteincoding gene as originally assumed but a W-encoded small RNA named Fem piRNA. The Fem piRNA controls female-specific splicing of the Bmdsx gene by downregulating expression of the Z-linked Masculinizer (Masc) gene. It is not known yet if the Fem piRNA-Masc sex-determining pathway is conserved in other Lepidoptera. Nevertheless, the $d s x$ function in sexual differentiation appears to be conserved at the bottom of a sex-determining cascade in many insects including Lepidoptera (Suzuki 2010; Gempe and Beye 2011). Thus, the $d s x$ gene may be a good target for the development of genetic sexing strains in pest Lepidoptera.

Advances in genetic technologies, especially in transgenesis, open up new possibilities for genetic sexing in Lepidoptera. Germ-line transformations, with a piggyBac transposable element, have been demonstrated - in the pink bollworm by Peloquin et al. (2000) and in the silkworm by Tamura et al. (2000). It has been suggested that genetic sexing strains based on a transgenic approach may be a possible solution to this problem (Marec et al. 2005), where the females would be transgenic but not the sterile males for release. Some progress in developing such strains has been reported in the codling moth (Marec et al. 2007) but this work has not yet been completed. Nevertheless, the feasibility of this approach has been demonstrated recently in the silkworm by the successful insertion of a transgene carrying the EGFP (enhanced green fluorescent protein) reporter into the W chromosome (Ma et al. 2013). Also, a new transgenic conditional lethal genetic sexing system has been developed in the silkworm (Tan et al. 2013) and in two pest species, the diamondback moth and the pink bollworm (Jin et al. 2013). This system is based on the tetracycline-repressible transactivator (tTAV) protein, which is expressed only in females through the alternatively spliced region of the pink bollworm $d s x$ gene $(P g d s x)$.

\section{ADVANTAGES OF INHERITED STERILITY VERSUS FULL STERILITY}

The unique characteristics of IS in Lepidoptera and other arthropods provide some inherent advantages over the use of full sterility in pest control programmes (North 1975). Since lepidopteran females generally are much more radiosensitive than males of the same species, the radiation dose may be adjusted to suit programme requirements, i.e. treated females are completely sterile and males partially sterile. 
When these partially sterile males mate with fertile females the radiation-induced deleterious effects are inherited by the $F_{1}$ generation. As a result egg hatch is reduced and the resulting $\left(F_{1}\right)$ offspring are both highly sterile and predominately male (Table 2). The lower dose of radiation used to induce $F_{1}$ sterility increases the quality and competitiveness of the released insects (North 1975) as measured by improved dispersal after release (Bloem et al. 2001), increased mating ability (Carpenter et al. 1987a), and superior sperm competitiveness (Carpenter et al. 1987a, 1997). In addition, because $F_{1}$ sterile progeny are produced in the field, the release of partially sterile males and fully sterile females is more compatible with other pest control mechanisms or strategies (Carpenter 1993; Cagnotti et al. 2016).

Table 2. Typical attributes of male lepidopteran insects (and their progeny) receiving substerilizing doses of radiation

\begin{tabular}{rcccrc}
\hline $\begin{array}{c}\text { Dose } \\
\text { applied } \\
\text { to } \mathrm{P}_{1}\end{array}$ & $\begin{array}{c}\text { Egg hatch } \\
(\%)\end{array}$ & $\begin{array}{c}\text { Larval mortality } \\
(\%)\end{array}$ & $\begin{array}{c}\text { Sex ratio } \\
\delta: \%\end{array}$ & \multicolumn{2}{c}{$\begin{array}{c}\text { Eg hatch } \\
(\%)\end{array}$} \\
\cline { 5 - 7 } & & 20.0 & $1.0: 1$ & 82.5 & 76.8 \\
\hline 0 & 71.8 & 51.1 & $2.6: 1$ & 10.8 & 13.9 \\
100 & 46.1 & 69.5 & $5.1: 1$ & 0.9 & 7.5 \\
200 & 30.8 & 75.1 & $7.0: 1$ & 0.8 & 6.1 \\
\hline
\end{tabular}

1. Reduced $\mathrm{F}_{1}$ egg hatch resulting from $\mathrm{P}_{1}$ (parental) generation

2. Increased mortality during $F_{1}$ development

3. Skewed sex ratio in favor of males in the $\mathrm{F}_{1}$ generation

4. Reduced $F_{2}$ egg hatch resulting from $F_{1}$ generation; sterility in $F_{2}$ generation higher than in $F_{1}$ generation

Data for codling moth (Bloem et al. 1999a)

Knipling (1970) used a mathematical model to explore the application of IS for control of lepidopteran pests (Barclay, this volume). He found that the release of partially sterile insects offered greater suppressive potential than the release of fully sterile insects, and suggested that the partially sterile-to-wild overflooding ratio could be as low as a one-quarter of what is normally required for fully sterile insects. Population models using data collected from several pest species (Walker and Pederson 1969; Brower and Tilton 1975; Carpenter et al. 1987a; Anisimov 1993; Carpenter and Layton 1993; Kean et al. 2011) corroborate Knipling's findings.

\section{POTENTIAL FOR INHERITED STERILITY TO SUPPRESS PEST POPULATIONS}

Field releases of partially sterile insects have demonstrated the usefulness of IS to control many lepidopteran pests, including the cabbage looper (North and Holt 1969), corn earworm (Carpenter and Gross 1993), gypsy moth (Mastro 1993), 
codling moth (Proverbs et al. 1978; Bloem et al. 1999b; Bloem et al. 2001), cactus moth (Hight et al. 2005), and many others (Bloem and Carpenter 2001; Simmons et al., this volume). The effect of $F_{1}$ sterility to influence pest populations has been most convincing when irradiated insects have been released in the field throughout the entire growing season. Season-long releases of irradiated (100 Gy) H. zea in mountain valleys of North Carolina, USA, delayed and/or reduced seasonal increases of wild H. zea males (Carpenter and Gross 1993). The incidence of H. zea larvae with chromosomal aberrations indicated that irradiated males were very competitive in mating with wild females, and were successful in producing $\mathrm{F}_{1}$ progeny, which further reduced the wild population. Release ratios averaged less than $5: 1$ overall, but reduced the wild population of $H$. zea by more than $70 \%$. In another case, season-long field studies of the codling moth were conducted in apple orchards in Washington State, USA, that compared: (1) twice-weekly releases of partially sterile codling moths treated with either 100 or $250 \mathrm{~Gy}$, and (2) combinations of mating disruption plus the release of partially sterile (100 Gy) codling moths, to control wild populations (Bloem et al. 2001). The results showed that fruit damage was significantly lower in all treatment plots when compared with control plots located outside the treatment areas.

\section{COMPATIBILITY OF INHERITED STERILITY WITH OTHER PEST CONTROL METHODS}

The success of releasing insects irradiated with substerilizing doses of radiation for the suppression of pest populations is influenced by the ability of released insects and their progeny to survive and interact with the wild population. Field survival rates for $F_{1}$ larvae from irradiated parents should be comparable with field survival of wild larvae because many of the deleterious effects induced by radiation are manifested and therefore eliminated during the $F_{1}$ egg stage (Carpenter et al. 1985). Any mortality agents such as insecticides, entomopathogens, and natural enemies (parasitoids and predators) could potentially interfere with the effectiveness of $F_{1}$ sterility if the agent killed a higher proportion of treated than wild larvae. Likewise host-plant resistance could potentially interfere with the effectiveness of $F_{1}$ sterility if the host-plant defenses somehow prevented a higher proportion of treated than wild larvae from establishing and developing on the host plant (Carpenter 1993).

The compatibility of different pest control methods with $F_{1}$ sterility has been investigated in both laboratory and field studies. Examples include the use of nuclear polyhedrosis viruses with $\mathrm{F}_{1}$ sterility for controlling $H$. zea and Spodoptera frugiperda (Hamm and Carpenter 1997), host-plant resistance and $\mathrm{F}_{1}$ sterility in $H$. zea and S. frugiperda (Carpenter and Wiseman 1992a, b), $\mathrm{F}_{1}$ sterility and insecticide resistance in $S$. frugiperda (Carpenter and Young 1991), $F_{1}$ sterility and a commercial formulation of Bacillus thuringiensis in $P$. opercullela, $\mathrm{F}_{1}$ sterility and synthetic pheromones to reduce wild populations of the codling moth (Bloem et al. 2001), and the use of parasitoids and $F_{1}$ sterility (Mannion et al. 1994, 1995; Carpenter et al. 1996; Bloem and Carpenter 2001; Cagnotti et al. 2016; Mangan and Bouyer, this volume). All studies have shown that $F_{1}$ sterility is compatible with other pest control methods. 


\section{POPULATION MODELS COMBINING THE EFFECTS OF $F_{1}$ STERILITY WITH OTHER CONTROL METHODS}

Knipling (1964), Barclay (1987), and Wong et al. (1992) recognized the potential benefit of combining sterile insects with conventional pest control methods. According to population models (Barclay 1987; Knipling 1992), combining inundative releases of natural enemies and sterile insects should yield additive or synergistic effects. Even though the SIT and natural enemies have different modes of action, the effectiveness of the SIT increases the ratio of natural enemies to adult hosts, and the effectiveness of natural enemies increases the ratio of sterile to fertile insects. Therefore, greater suppression could be expected if parasitoid releases were combined with the $F_{1}$ sterility technique (Carpenter 1993). Not only is $F_{1}$ sterility theoretically more effective than full sterility in reducing population increase (Carpenter et al. 1987a), but $F_{1}$ sterility results in the production of sterile $F_{1}$ eggs and larvae that provide an increased number of hosts for parasitoids. As a result, the number of parasitoids produced should increase even if the rate of parasitism remained the same (host-density independent), and whether or not additional parasitoids are released. Although population models (that independently consider augmentative releases of parasitoids (Knipling 1992) and $F_{1}$ sterility (Carpenter et al. 1987a)) suggest that both methods are highly efficacious, integrating lepidopteran $\mathrm{F}_{1}$ sterility and augmentative biological control results in synergistic effects (Carpenter 1993). Therefore, the greatest impact of $F_{1}$ sterility and augmentative parasitoid releases as area-wide methods against lepidopteran pests can be realized only when the two methods are integrated (Barclay, this volume).

Population models also provide insight into how different control strategies could be combined for greatest efficiency. Although the effectiveness of $F_{1}$ sterility continues to increase as the ratio of irradiated to non-irradiated insects increases, the efficiency per released moth declines. A similar loss of efficiency occurs in parasitoid releases (Carpenter 1993). According to these models the economic benefit of combining $F_{1}$ sterility and parasitoid augmentation would be greatest when the ratios of irradiated to non-irradiated, and parasitoid to host, are low (i.e. equal to or less than 10:1). The model presented in Fig. 5 demonstrates that population suppression is increased when $F_{1}$ sterility and parasitoid releases are combined, and that the percentage reduction in population growth is greater when parasitized hosts produce adult parasitoids than when no parasitoids are produced (Carpenter 2000).

\section{INHERITED STERILITY IN COMBINATION WITH BIOLOGICAL CONTROL}

Fully successful integration of $F_{1}$ sterility and parasitoid augmentation into a management approach can occur only if parasitoids do not negatively impact irradiated insects and their progeny more than that of the wild population, and if $F_{1}$ sterility does not negatively impact the efficacy and reproduction of parasitoids. Knowledge of any negative impact of $F_{1}$ sterility on parasitoids would be important before implementing an AW-IPM programme using $\mathrm{F}_{1}$ sterility. For example, if 
parasitoids that attack the $F_{1}$ sterile progeny are unable to develop normally, and most of the hosts present are $F_{1}$ sterile progeny, then there could be a negative impact on subsequent parasitoid populations. Conversely, if parasitoids develop normally on $\mathrm{F}_{1}$ eggs, larvae, and pupae, then the greater number of hosts available would allow for an increase in the parasitoid population. Since many hosts of the $F_{1}$ generation would experience genetically-induced mortality before they reached the adult stage, any parasitoids able to develop on these hosts would result in a positive and synergistic increase in the efficacy of an AW-IPM programme (Carpenter 2000).

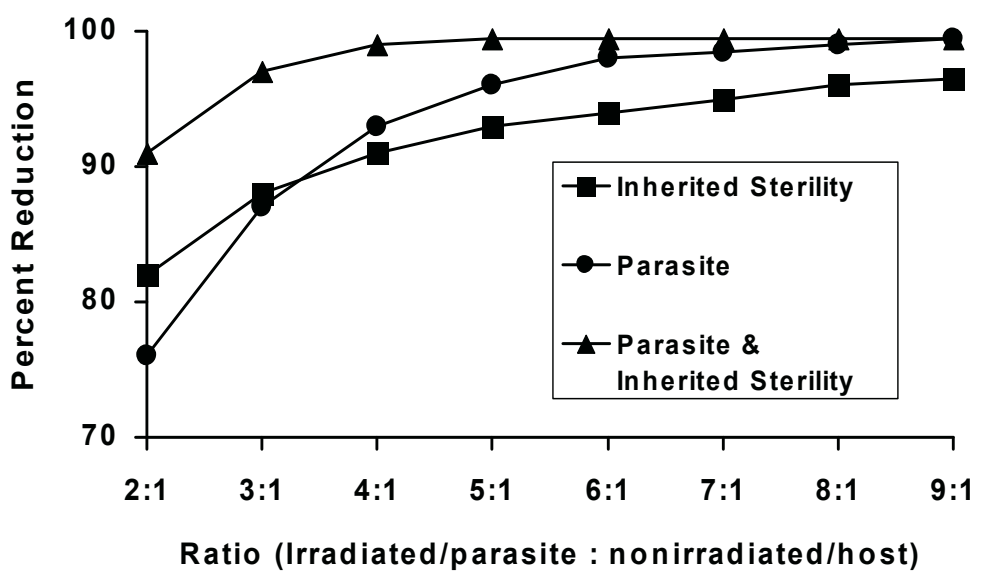

Figure 5. Comparison of the projected reduction in normal population growth when only parasitoids [parasites] are released (Knipling 1992), when only irradiated (100 Gy) male moths are released (Carpenter et al. 1987c), and when releases are equally divided between parasitoids and irradiated male moths.

Field, greenhouse and laboratory studies compared the acceptability and suitability of progeny from irradiated (100 Gy) and untreated Spodoptera exigua males as hosts for the braconid larval parasitoid Cotesia marginiventris (Cresson) (Carpenter et al. 1996), and progeny from irradiated (100 Gy) and untreated H. zea males as hosts for the tachinid Archytas marmoratus (Townsend) (Mannion et al. 1994, 1995). Results from these studies demonstrated that progeny of irradiated males and untreated females were acceptable and equally suitable hosts for parasitoid development. Female parasitoids showed no oviposition preference for progeny from females paired with either irradiated or untreated males. Other studies on different lepidopteran pests also have reported compatibility between the two control methods (Bloem and Carpenter 2001).

There are many different scenarios in which $F_{1}$ sterility could be integrated with natural enemies to suppress pest populations (Carpenter 1993; Hendrichs et al. 2009) (Box 1). The release of partially sterile males and fully sterile females would produce large numbers of $F_{1}$ eggs and larvae that could be field-reared on earlyseason host plants or crop plants that tolerate some larval feeding damage, e.g. 
whorl-stage corn. Natural enemies (native and/or released) could use the $\mathrm{F}_{1}$ eggs, larvae and pupae as hosts and thereby substantially increase the natural enemy population for the next generation of the pest insect (Proshold et al. 1998). Also surviving sterile $F_{1}$ progeny would produce sterile adults that would negatively impact the next generation of the pest insect. If the economic injury level of cultivated host plants indicated that the additional sterile $\mathrm{F}_{1}$ larvae were undesirable, then the dose of radiation could be increased to a level that would reduce or eliminate the number of progeny from irradiated females, or releases could be limited to irradiated males.

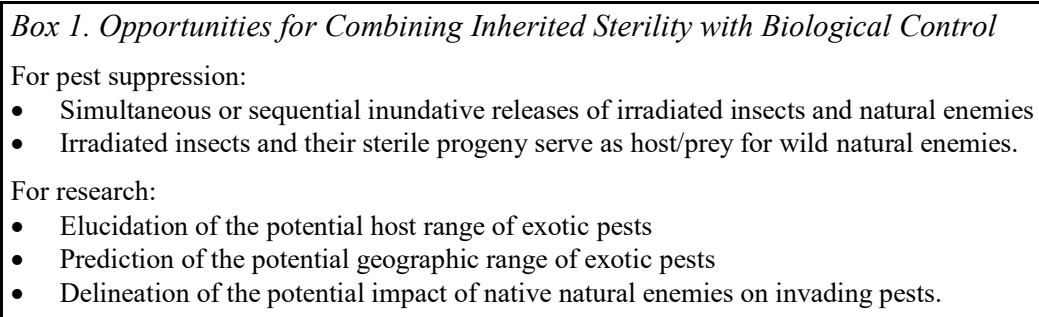

Although the compatibility of $F_{1}$ sterility with the application of synthetic organic insecticides has been demonstrated (Carpenter and Young 1991), parasitoids and/or predators generally are not compatible with these products. When insecticides are required to reduce pest infestations, insect growth regulators or other formulations that are compatible with natural enemies should be considered. Another management option would be to establish host plants for the pest in insecticide-free areas adjacent to insecticide-treated crops. Host plants could be artificially infested with pest larvae to provide natural enemies (native and/or released) with an adequate supply of hosts. If the pest larvae used in the artificial infestations (nursery crops) were sterile, i.e. the progeny of irradiated parents, then non-parasitized larvae would not contribute to the increase of the wild population but would produce sterile adults that would negatively impact the next generation of the pest insect (Okine et al. 1998; Carpenter 2000).

In addition to using $F_{1}$ sterility as a direct pest control method, there are opportunities to use $F_{1}$ sterility to facilitate the development of other pest suppression methods. For example the $\mathrm{F}_{1}$ sterile progeny (eggs, larvae and pupae) of a pest may be used as hosts/prey for natural enemies that are shipped commercially, especially in quarantine-sensitive shipments (Hendrichs et al. 2009). The use of sterile insects in commercial shipments would ameliorate concerns regarding the reproductive viability of non-parasitized and non-consumed pests upon arrival at the shipment destination. Also the use of $F_{1}$ sterile progeny as hosts for parasitoids would eliminate the need to wait for non-parasitized pests (either eggs or pupae) to emerge before shipment of the parasitized pest (Greany and Carpenter 2000; Hendrichs et al. 2009). 


\section{ADDITIONAL APPLICATIONS OF $F_{1}$ STERILITY FOR RESEARCH AND MANAGEMENT}

Greany and Carpenter (2000) reported that $F_{1}$ sterility could provide a new risk management tool for assessing the safety of exotic lepidopterans being considered as biological control agents against invasive weeds (Moeri et al. 2009; Tate et al. 2009) (Box 1). Production of $F_{1}$ sterile progeny permits developmental and behavioral observations to be made under actual field conditions without concern that a breeding population would be established (Carpenter et al. 2001a). This facilitates field observations on oviposition behaviours and host associations, larval feeding preferences, and larval development and survival on both target and non-target plant species. Also, the impact that native natural enemies might have on exotic candidate species being considered as biological control agents for invasive weeds, and the ability of these candidate species to survive and overwinter under various climatic conditions could be studied in the field through this innovative application of $F_{1}$ sterility.

$F_{1}$ sterility could be used to conduct research on exotic pests that are expanding their geographical range. Strom et al. (1996) suggested that gypsy moth host preferences, or the quality of potential hosts outside the generally infested area, could be investigated using releases of $\mathrm{F}_{1}$ sterile larvae of $L$. dispar. In addition to host range studies, Carpenter et al. (2001a) suggested that $F_{1}$ sterility could be used to predict the potential geographic range and to evaluate the potential impact of native natural enemies on the rate of spread of exotic lepidopteran pests.

\section{CHALLENGES AND OPPORTUNITIES}

Challenges are inherent in all pest management methods, and Whitten and Mahon (this volume) discuss constraints and misconceptions unique to the SIT. In addition to those in common with the SIT, the major challenge to the use of IS is the perception that sterile $\mathrm{F}_{1}$ larvae cause economic damage to crops, especially highvalue crops such as fruit. Consequently, low doses of radiation, which would certainly result in more competitive insects, are often avoided. For example, Proverbs et al. (1978) found that codling moths treated with 250 Gy were more competitive in the field, and provided better control, than did fully sterile moths (400 Gy). Nevertheless, in spite of these findings, Proverbs et al. (1982) continued to be concerned that $F_{1}$ larvae would cause economic damage, and used 350 Gy to irradiate moths released in a pilot study conducted in British Columbia, Canada, from 1976-1978. Also, in the current codling moth programme in British Columbia, Canada, which began field operations in 1994, moths treated with 350 Gy are released, even though doses as low as 100 Gy have been suggested (Anisimov 1993; Bloem et al. 1999a, 1999b). It was found in field studies that season-long releases of moths treated with 100 Gy did not cause fruit injury (Fig. 6), and moths receiving 100 Gy were more competitive than those receiving 250 Gy (Bloem et al. 2001). These studies indicate that fears of increased fruit (or plant) injury resulting from $\mathrm{F}_{1}$ larvae are ill founded, especially when the radiation dose causes partial sterility in males and full sterility in females. Therefore, the production of sterile $F_{1}$ larvae 
should be seen not as a problem but rather an opportunity to enhance the production of natural enemies and to produce more competitive sterile moths in the field.

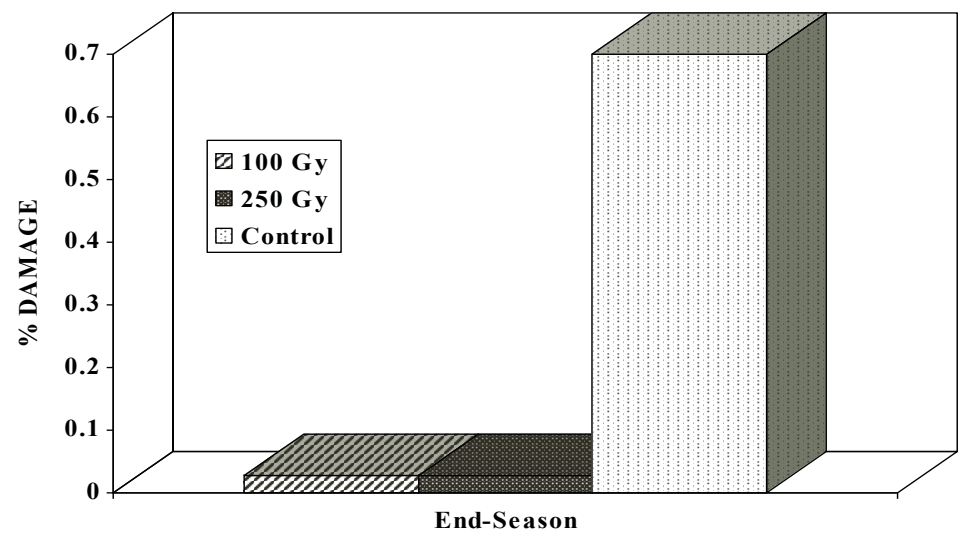

Figure 6. Percentage fruit damage at harvest caused by the codling moth in apple orchards in Washington State, USA. One series of three plots received season-long releases of partially sterile codling moths treated with $100 \mathrm{~Gy}$ (female moths were $100 \%$ sterile, and males $50 \%$ sterile). A second group of plots received 250-Gy-treated moths (females $100 \%$ sterile, and males $75 \%$ sterile). The control areas were treated with six applications of azinphosmethyl insecticide. At the end of the fruiting season, 2500 fruit per treatment were sampled (Bloem et al. 2001).

\section{REFERENCES}

Ahmed, M. S. H., Z. Al-Hakkar, and A. Al-Saqur. 1971. Exploratory studies on the possibility of integrated control of the fig moth Ephestia cautella Walk, pp. 1-6. In Proceedings, Panel: Application of Induced Sterility for Control of Lepidopterous Populations. Joint FAO/IAEA Division of Atomic Energy in Food and Agriculture, 1-5 June 1970, Vienna, Austria. STI/PUB/281. IAEA, Vienna, Austria. https://www.iaea.org/sites/default/files/el_lepidopterous_sterility_1971.pdf

Ahola, V., R. Lehtonen, P. Somervuo, L. Salmela, P. Koskinen, P. Rastas, N. Välimäki, L. Paulin, J. Kvist, N. Wahlberg, J. Tanskanen, E. A. Hornett, L. C. Ferguson, S. Luo, Z. Cao, M. A. de Jong, A. Duplouy, O.-P. Smolander, H. Vogel, R. C. McCoy, K. Qian, W. S. Chong, Q. Zhang, F. Ahmad, J. K. Haukka, A. Joshi, J. Salojärvi, C. W. Wheat, E. Grosse-Wilde, D. Hughes, R. Katainen, E. Pitkänen, J. Ylinen, R. M. Waterhouse, M. Turunen, A. Vähärautio, S. P. Ojanen, A. H. Schulman, M. Taipale, D. Lawson, E. Ukkonen, V. Mäkinen, M. R. Goldsmith, L. Holm, P. Auvinen, M. J. Frilander, and I. Hanski. 2014. The Glanville fritillary genome retains an ancient karyotype and reveals selective chromosomal fusions in Lepidoptera. Nature Communications 5: 4737. DOI:10.1038/ncomms5737 http://www.nature.com/articles/ncomms5737

Al-Taweel A. A., M. S. H. Ahmed, S. S. Kadhum, and A.A. Hameed. 1990. Effects of gamma radiation on the progeny of irradiated Ephestia cautella (Walker) (Lepidoptera: Pyralidae) males. Journal of Stored Products Research 26: 233-236.

Ameresekere, R. V. W. E., and G. P. Georghiou. 1971. Sterilization of the beet leafhopper: induction of sterility and evaluation of biotic effects with a model sterilant (OM-53139) and ${ }^{60}$ Co irradiation. Journal of Economic Entomology 64: 1074-1080.

Anisimov, A. I. 1993. Study of the mechanism and possibilities of using $F_{1}$ sterility for genetic control of codling moth, pp. 135-155. In Proceedings: Radiation Induced $\mathrm{F}_{1}$ Sterility in Lepidoptera for Area-Wide Control. Final Research Co-ordination Meeting, Joint FAO/IAEA Division of Nuclear 
Techniques in Food and Agriculture, 9-13 September 1991, Phoenix, AZ, USA. STI/PUB/929. IAEA, Vienna, Austria.

https://www.iaea.org/sites/default/files/ipc-radiation-inherited-sterility-area-wide-control.pdf

Anisimov, A. I., N. V. Lazurkina, and A. N. Shvedov. 1989. Influence of radiation-induced genetic damage on the suppressive effect of inherited sterility in the codling moth (Lepidoptera: Tortricidae). Annals of the Entomological Society of America 82: 769-777.

Arthur, V., F. M. Maximiliano-Wiendl, J. A. Duarte-Aguilar, and R. E. Domarco. 1993. Effect of gamma radiation at pupal stage on fall armyworm parent and $F_{1}$ generation reproduction, pp. 73-79. In Proceedings: Radiation Induced $\mathrm{F}_{1}$ Sterility in Lepidoptera for Area-Wide Control. Final Research Co-ordination Meeting, Joint FAO/IAEA Division of Nuclear Techniques in Food and Agriculture, 9-13 September 1991, Phoenix, AZ, USA. STI/PUB/929. IAEA, Vienna, Austria.

https://www.iaea.org/sites/default/files/ipc-radiation-inherited-sterility-area-wide-control.pdf

Ashrafi, S. H., and R. M. Roppel. 1973. Radiation-induced partial sterility related to structurally abnormal sperms of Plodia interpunctella. Annals of the Entomological Society of America 66: 1309-1314.

Ashrafi, S. H., E. W. Tilton, and J. H. Brower. 1972. Inheritance of radiation-induced partial sterility in the Indian meal moth. Journal of Economic Entomology 65: 1265-1268.

Astaurov, B. I., and S. L. Frolova. 1935. Artificial mutations in the silkworm (Bombyx mori L.). V. Sterility and spermatogenic anomalies in the progeny of irradiated moths concerning some questions of general biological and mutagenic action of X-rays. Biologicheskii Zhurnal 4: 861-894.

Ayvaz, A., and A. Ş. Tunçbilek. 2006. Effects of gamma radiation on life stages of the Mediterranean flour moth, Ephestia kuehniella Zeller (Lepidoptera: Pyralidae). Journal of Pest Science 79: 215-222. https://doi.org/10.1007/s10340-006-0137-6

Ayvaz, A., S. Albayrak, and A. Ş. Tunçbilek. 2007. Inherited sterility in Mediterranean flour moth Ephestia kuehniella Zeller (Lepidoptera: Pyralidae): effect of gamma radiation on insect fecundity, fertility and developmental period. Journal of Stored Products Research 43: 234-239. DOI: 10.1016/j.jspr.2006.06.003 https://doi.org/10.1016/j.jspr.2006.06.003

Ayvaz, A., S. Albayrak, and S. Karaborklu. 2008. Gamma radiation sensitivity of the eggs, larvae and pupae of Indian meal moth Plodia interpunctella (Hübner) (Lepidoptera: Pyralidae). Pest Management Science 64: 505-512. http://onlinelibrary.wiley.com/doi/10.1002/ps.1526/abstract

Barbulescu, A., and I. Rosca. 1993. Possibilities of using radiation induced $F_{1}$ sterility for control of European corn borer in Romania, pp. 101-115. In Proceedings: Radiation Induced $F_{1}$ Sterility in Lepidoptera for Area-Wide Control. Final Research Co-ordination Meeting, Joint FAO/IAEA Division of Nuclear Techniques in Food and Agriculture, 9-13 September 1991, Phoenix, AZ, USA. STI/PUB/929. IAEA, Vienna, Austria. https://www.iaea.org/sites/default/files/ipc-radiation-inherited-sterility-area-wide-control.pdf

Barclay, H. J. 1987. Models of sterile insect releases for populations under attack by parasitoids. Ecological Modeling 36: 155-169.

Bariola, L. A., A. C. Bartlett, R. T. Staten, R. W. Rosander and J. C. Keller. 1973. Partially sterilized adult pink bollworms: releases in field cages and field cause chromosomal aberrations. Environmental Entomology 2: 173.

Bartlett, A. C. 1989. Genetics of the pink bollworm, Pectinophora gossypiella. Agricultural Zoology Reviews 3: 31-51.

Bartlett, A. C., and F. E. Del Fosse. 1991. The pachytene karyotype of the pink bollworm (Lepidoptera: Gelechiidae). Southwestern Entomologist 16: 223-235.

Bauer, H. 1967. Die kinetische Organisation der Lepidopteren-Chromosomen. Chromosoma 22: 102125.

Berg, G. J., and L. E. LaChance. 1976. Dominant lethal mutations in insects with holokinetic chromosomes: irradiation of pink bollworm sperm. Annals of the Entomological Society of America 69: 971-976.

Bloem, S., and J. E. Carpenter. 2001. Evaluation of population suppression by irradiated Lepidoptera and their progeny. Florida Entomologist 84: 165-171. http://www.fcla.edu/FlaEnt/fe84p165.pdf

Bloem, S., K. A. Bloem, J. E. Carpenter, and C. O. Calkins. 1999a. Inherited sterility in codling moth (Lepidoptera: Tortricidae): effect of substerilizing doses of radiation on insect fecundity, fertility and control. Annals of the Entomological Society of America 92: 222-229.

Bloem, S., K. A. Bloem, J. E. Carpenter, and C. O. Calkins. 1999b. Inherited sterility in codling moth (Lepidoptera: Tortricidae): effect of substerilizing doses of radiation on field competitiveness. Environmental Entomology 28: 669-674. https://doi.org/10.1093/ee/28.4.669 
Bloem, S., K. A. Bloem, J. E. Carpenter, and C. O. Calkins. 2001. Season-long releases of partially sterile males for control of codling moth, Cydia pomonella (Lepidoptera: Tortricidae), in Washington apples. Environmental Entomology 30: 763-769. https://doi.org/10.1603/0046-225X-30.4.763

Bloem, S., J. E. Carpenter, and K. A. Bloem. 2003a. Performance of sterile Cactoblastis cactorum (Lepidoptera: Pyralidae) females in luring males to traps. Florida Entomologist 86: 395-399. http://www.fcla.edu/FlaEnt/fe86p395.pdf

Bloem, S., J. E. Carpenter, and J. H. Hofmeyr. 2003b. Radiation biology and inherited sterility in false codling moth (Lepidoptera: Tortricidae). Journal of Economic Entomology 96: 1724-1731. https://doi.org/10.1603/0022-0493-96.6.1724

Brower, J. H. 1976. Irradiation of pupae of the Indian meal moth to induce sterility or partial sterility in adults. Journal of Economic Entomology 69: 277-281.

Brower, J. H. 1979. Sub-sterilizing irradiation of Plodia interpunctella males: effects of three filial generations. Annals of the Entomological Society of America 72: 716-720.

Brower, J. H. 1980. Inheritance of partial sterility in progeny of irradiated males of Ephestia cautella (Lepidoptera: Pyralidae) and its effect on theoretical population suppression. Canadian Entomologist 112: $131-140$.

Brower, J. H. 1981. Reproductive performance of inbred or outbred $F_{1}$ and $F_{2}$ progeny of adult Indian meal moth females or males $\mathrm{x}$ females partially sterilized by gamma irradiation. Annals of the Entomological Society of America 74: 108-113.

Brower, J. H. 1982. Mating competitiveness of irradiation sub-sterilized males of the tobacco moth, Ephestia cautella. Journal of Economic Entomology 75: 454-457.

Brower, J. H., and E. W. Tilton. 1975. Potential for control of Cadra cautella (Walker) by release of fully or partially sterile males. International Journal of Applied Radiology and Isotopes 26: 720-725.

Brown, S. W., and W. A. Nelson-Rees. 1961. Radiation analysis of a lecanoid genetic system. Genetics 46: $983-1007$

Bushland, R. C. 1971. Sterility principle for insect control. Historical development and recent innovations, pp. 3-14. In Proceedings, Symposium: Sterility Principle for Insect Control or Eradication. Food and Agriculture Organization of the United Nations, and International Atomic Energy Agency, 14-18 September 1970, Athens, Greece. STI/PUB/265. IAEA, Vienna, Austria. https://www.iaea.org/sites/default/files/18/03/1_new_spinconerad71-cvr-1-2-full.pdf

Cagnotti, C. L., M. M. Viscarret, M. B. Riquelme, E. $\overline{\text { N} . ~ B o t t o, ~ L . ~ Z . ~ C a r a b a j a l, ~ D . ~ F . ~ S e g u r a, ~ a n d ~ S . ~}$ N. López. 2012. Effects of X-rays on Tuta absoluta for use in inherited sterility programmes. Journal of Pest Science 85: 413-421. https://link.springer.com/article/10.1007/s10340-012-0455-9

Cagnotti, C. L., A. V. Andorno, C. M. Hernández, L. Carabajal Paladino, E. N. Botto, and S. N. López. 2016. Inherited sterility in Tuta absoluta (Lepidoptera: Gelechiidae): pest population suppression and potential for combined use with a generalist predator. Florida Entomologist 99 (Special Issue 1): 87-94. https://doi.org/10.1653/024.099.sp112

Carabajal Paladino, L. Z., M. E. Ferrari, J. P. Lauría, C. L. Cagnotti, J. Šíchová, and S. N. López. 2016. The effect of $X$-rays on cytological traits of Tuta absoluta (Lepidoptera: Gelechiidae). Florida Entomologist 99 (Special Issue 1): 43-53. https://doi.org/10.1653/024.099.sp107

Carpenter, J. E. 1991. Effect of radiation dose on the incidence of visible chromosomal aberrations in Helicoverpa zea (Lepidoptera: Noctuidae). Environmental Entomology 20: 1457-1459.

Carpenter, J. E. 1992. Sperm precedence in Helicoverpa zea (Lepidoptera: Noctuidae): response to a substerilizing dose of radiation. Journal of Economic Entomology 85: 779-782.

Carpenter, J. E. 1993. Integration of inherited sterility and other pest management strategies for Helicoverpa zea, pp. 363-370. In Proceedings: Management of Insect Pests: Nuclear and Related Molecular and Genetic Techniques. FAO/IAEA International Symposium, 19-23 October 1992, Vienna, Austria. STI/PUB/909. IAEA, Vienna, Austria. https://www.iaea.org/publications/3782/management-of-insect-pests-nuclear-and-related-molecularand-genetic-techniques

Carpenter, J. E. 2000. Area-wide integration of lepidopteran $F_{1}$ sterility and augmentative biological control, pp. 193-200. In K. H. Tan (ed.), Proceedings: Area-Wide Control of Fruit Flies and Other Insect Pests. International Conference on Area-Wide Control of Insect Pests, and the $5^{\text {th }}$ International Symposium on Fruit Flies of Economic Importance, 28 May-5 June 1998, Penang, Malaysia. Penerbit Universiti Sains Malaysia, Pulau Pinang, Malaysia. http://www-naweb.iaea.org/nafa/ipc/public/Area-wide-control_73-229.pdf

Carpenter, J. E., and H. R. Gross. 1989. Interaction of inherited sterility and diapause in the corn earworm (Lepidoptera: Noctuidae). Journal of Economic Entomology 82: 1354-1357. 
Carpenter, J. E., and H. R. Gross. 1993. Suppression of feral Helicoverpa zea (Lepidoptera: Noctuidae) populations following the infusion of inherited sterility from released substerile males. Environmental Entomology 22: 1084-1091.

Carpenter, J. E., and R. C. Layton. 1993. Computer model for predicting the effect of inherited sterility on population growth, pp. 49-55. In Proceedings: Radiation Induced $\mathrm{F}_{1}$ Sterility in Lepidoptera for Area-Wide Control. Final Research Co-ordination Meeting, Joint FAO/IAEA Division of Nuclear Techniques in Food and Agriculture, 9-13 September 1991, Phoenix, AZ, USA. STI/PUB/929. IAEA, Vienna, Austria.

https://www.iaea.org/sites/default/files/ipc-radiation-inherited-sterility-area-wide-control.pdf

Carpenter, J. E., and B. R. Wiseman. 1992a. Effects of inherited sterility and insect resistant dentcorn silks on Helicoverpa zea (Lepidoptera: Noctuidae) development. Journal of Entomological Science 27: 413-420.

Carpenter, J. E., and B. R. Wiseman. 1992b. Spodoptera frugiperda (Lepidoptera: Noctuidae) development and damage potential as affected by inherited sterility and host plant resistance. Environmental Entomology 21: 57-60.

Carpenter, J. E., and J. R. Young. 1991. Interaction of inherited sterility and insecticide resistance in the fall armyworm (Lepidoptera: Noctuidae). Journal of Economic Entomology 84: 25-27.

Carpenter, J. E., J. R. Young, E. F. Knipling, and A. N. Sparks. 1983. Fall armyworm (Lepidoptera: Noctuidae): inheritance of gamma-induced deleterious effects and potential for pest control. Journal of Economic Entomology 76: 378-382.

Carpenter, J. E., J. R. Young, and A. N. Sparks. 1985. Fall armyworm (Lepidoptera: Noctuidae): field survival of $F_{1}$ larvae from partially sterile parents. Florida Entomologist 68: 290-296. http://fulltext10.fcla.edu/DLData/SN/SN00154040/0068_002/98p0146k.pdf

Carpenter, J. E., J. R. Young, and A. N. Sparks. 1986. Fall armyworm (Lepidoptera: Noctuidae): comparison of inherited deleterious effects in progeny from irradiated males and females. Journal of Economic Entomology 79: 47-49.

Carpenter, J. E. A. N. Sparks, and H. L. Cromroy. 1987a. Corn earworm (Lepidoptera: Noctuidae): influence of irradiation and mating history on the mating propensity of females. Journal of Economic Entomology 80: 1233-1237.

Carpenter, J. E., J. R. Young, H. L. Cromroy, and A. N. Sparks. 1987b. Corn earworm (Lepidoptera: Noctuidae): comparison of field survival of larvae from normal and irradiated parents. Journal of Economic Entomology 80: 883-886.

Carpenter, J. E., J. R. Young, A. N. Sparks, H. L. Cromroy, and M. A. Chowdhury. 1987c. Corn earworm (Lepidoptera: Noctuidae): effects of substerilizing doses of radiation and inherited sterility on reproduction. Journal of Economic Entomology 80: 483-489.

Carpenter, J. E., A. N. Sparks, S. D. Pair, and H. L. Cromroy. 1989. Heliothis zea (Lepidoptera: Noctuidae): effects of radiation and inherited sterility on mating competitiveness. Journal of Economic Entomology 82: 109-113.

Carpenter, J. E., Hidryani, and W. Sheehan. 1996. Compatibility of $F_{1}$ sterility and a parasitoid, Cotesia marginiventris (Hymenoptera: Braconidae), for managing Spodoptera exigua (Lepidoptera: Noctuidae): acceptability and suitability of host. Florida Entomologist 79: 289-295. http://www.fcla.edu/FlaEnt/fe79p289.pdf

Carpenter, J. E., Hidryani, N. Nelly, and B. G. Mullinix. 1997. Effect of substerilizing doses of radiation on sperm precedence in fall armyworm (Lepidoptera: Noctuidae). Journal of Economic Entomology 90: 444-448.

Carpenter, J. E., K. A. Bloem, and S. Bloem. 2001a. Applications of $F_{1}$ sterility for research and management of Cactoblastis cactorum (Lepidoptera: Pyralidae). Florida Entomologist 84: 531-536. http://www.fcla.edu/FlaEnt/fe84p531.pdf

Carpenter, J. E., S. Bloem, and K. A. Bloem. 2001b. Inherited sterility in Cactoblastis cactorum (Lepidoptera: Pyralidae). Florida Entomologist 84: 537-542. http://www.fcla.edu/FlaEnt/fe84p537.pdf

Caspari, E. W., and F. J. Gottlieb. 1975. The Mediterranean meal moth, Ephestia kühniella, pp. 125147. In R. C. King (ed.), Handbook of genetics, Volume3. Plenum Press, New York, NY, USA.

Chand, A. T. and S. S. Sehgal. 1982. Gamma irradiation of the larval stage of rice moth: effects on mating frequency, fecundity and fertility of the adults and inheritance of radiation-induced sterility. Annals of Agricultural Research 3: 69-75. 
Chandna, S., B. S. Dwarakanath, R. K. Seth, D. Khaitan, J. S. Adhikari, and V. Jain. 2004. Radiation responses of Sf9, a highly radioresistant lepidopteran insect cell line. International Journal of Radiation Biology 80: 301-315. https://doi.org/10.1080/09553000410001679794

Charmillot, P. J. 1977. Lutte autocide contre le carpocapse (Laspeyresia pomonella L.): 3. Lachers de papillons substeriles. Bulletin de la Societe Entomologique Suisse 50: 203-212.

Charmillot, P. J., A. Fossati, and J. Stahl. 1973. Production de males steriles du carpocapse des pommes (Laspeyresia pomonella L.) descendant de parents substeriles et examen de leur competitivite en vue de la lutte autocide. Schweizerische Landwirtschaftliche Forschung 12: 181188.

Cheng, W. Y., and D. T. North. 1972. Inherited sterility in the $F_{1}$ progeny of irradiated male pink bollworms. Journal of Economic Entomology 65: 1272-1275.

Cogburn, R. R., E. W. Tilton, and W. E. Burkholder. 1966. Gross effects of gamma radiation on the Indian meal moth and the Angoumois grain moth. Journal of Economic Entomology 59: 682-684.

Cook, P. A., and N. Wedell. 1996. Ejaculate dynamics in butterflies: a strategy for maximizing fertilization success? Proceedings of the Royal Society of London B Biological Sciences 263: 10471051.

Cook, P. A., and N. Wedell. 1999. Non-fertile sperm delay female remating. Nature 397: 486.

Curtis, C. F. 1969. The production of partially sterile mutants in Glossina austeni. Genetical Research 13: 289-301.

Curtis, C. F., P. A. Langley, A. R. Mews, E. D. Offori, D. I. Southern, and P. F. Pell. 1973. Sex ratio distortion and semi-sterility in the progeny of irradiated Glossina morsitans. Genetical Research 21: $153-165$.

Debolt, J. W. 1973. Preliminary investigation of the effects of gamma irradiation on the fertility, survival, and mating competitiveness of the beet armyworm, Spodoptera exigua, pp. 1158-1161. In $3^{\text {rd }}$ National Symposium on Radioecology 2.

Delrio, G., and R. Cavalloro. 1975. Sterilite hereditaire chez Gonocerus acuteangulatus Goeze (Rhynchote, Coreidae), pp. 423-435. In Proceedings, Symposium: Sterility Principle for Insect Control 1974. Food and Agriculture Organization of the United Nations, and International Atomic Energy Agency, 22-26 July 1974, Innsbruck, Austria. STI/PUB/377. IAEA, Vienna, Austria. https://www.iaea.org/sites/default/files/18/03/ipc-sterility-insects-1975_1-cvr_full.pdf

Elnagar, S., M. M. Megahed, H. A. Sallam, and S. M. Ibrahim. 1984. Inherited sterility among Agrotis ipsilon laboratory population exposed to gamma irradiation. Insect Science and its Application 5: 501-503.

Ercelik, T. M., and G. G. Holt. 1972. Sterility inherited by the progeny of male cabbage loopers irradiated in various stages of development. Environmental Entomology 1: 592-596.

Flint, H. M., D. L. Palmer, L. A. Bariola, and B. Horn. 1974. Suppression of populations of native pink bollworm in field cages by the release of irradiated moths. Journal of Economic Entomology 67: $55-57$.

Fossati, A., J. Stahl, and J. Granges. 1971. Effect of gamma irradiation dose on the reproductive performance of the $\mathrm{P}$ and $\mathrm{F}_{1}$ generations of the codling moth Laspeyresia pomonella, pp. 41-47. In Proceedings, Panel: Application of Induced Sterility for Control of Lepidopterous Populations. Joint FAO/IAEA Division of Atomic Energy in Food and Agriculture, 1-5 June 1970, Vienna, Austria. STI/PUB/281. IAEA, Vienna, Austria. https://www.iaea.org/sites/default/files/el_lepidopterous_sterility_1971.pdf

Friedländer, M. 1997. Control of the eupyrene-apyrene sperm dimorphism in Lepidoptera. Journal of Insect Physiology 43: 1085-1092.

Friedländer, M., R. K. Seth, and S. E. Reynolds. 2005. Eupyrene and apyrene sperm: dichotomous spermatogenesis in Lepidoptera. Advances in Insect Physiology 32: 206-308. https://doi.org/10.1016/S0065-2806(05)32003-0

Fu, H., F. W. Zhu, Y. Y. Deng, Q. F. Weng, M. Y. Hu, and T. Z. Zhang. 2016. Development, reproduction and sexual competitiveness of Conopomorpha sinensis (Lepidoptera: Gracillariidae) gamma-irradiated as pupae and adults. Florida Entomologist 99 (Special Issue 1): 66-72. http://journals.fcla.edu/flaent/article/view/88487

Fujii, H., Y. Banno, H. Doira, H. Kihara, and Y. Kawaguchi. 1998. Genetical stocks and mutations of Bombyx mori: important genetic resources, 2nd ed. Isseido, Fukuoka, Japan.

Fujii, T., and T. Shimada. 2007. Sex determination in the silkworm, Bombyx mori: a female determinant on the $\mathrm{W}$ chromosome and the sex-determining gene cascade. Seminars in Cell \& Developmental Biology 18: 379-388. https://doi.org/10.1016/j.semcdb.2007.02.008 
Fuková, I., L. G. Neven, N. M. Bárcenas, N. A. Gund, M. Dalíková, and F. Marec. 2009. Rapid assessment of the sex of codling moth Cydia pomonella (Linnaeus) (Lepidoptera: Tortricidae) eggs and larvae. Journal of Applied Entomology 133: 249-261. http://onlinelibrary.wiley.com/doi/10.1111/j.1439-0418.2008.01352.x/full

Gage, M. J. G., and P. A. Cook. 1994. Sperm size and numbers? Effects of nutritional stress upon eupyrene and apyrene sperm production strategies in the moth Plodia interpunctella (Lepidoptera: Pyralidae). Functional Ecology 8: 594-599.

García, J. C., and J. R. González. 1993. $F_{1}$ sterility of Diatraea saccharalis (Fab.), Lepidoptera: Crambidae. I. Effects of substerilizing doses on reproduction and competitiveness, pp. 405-418. In Proceedings: Management of Insect Pests: Nuclear and Related Molecular and Genetic Techniques. FAO/IAEA International Symposium, 19-23 October 1992, Vienna, Austria. STI/PUB/909. IAEA, Vienna, Austria. https:/www.iaea.org/publications/3782/management-of-insect-pests-nuclear-andrelated-molecular-and-genetic-techniques

Gassner, G., and D. J. Klemetson. 1974. A transmission electron microscope examination of Hemipteran and Lepidopteran gonial centromeres. Canadian Journal of Genetics and Cytology 16: 457-464.

Gempe, T., and M. Beye. 2011. Function and evolution of sex determination mechanisms, genes and pathways in insects. BioEssays 33: 52-60. http://onlinelibrary.wiley.com/doi/10.1002/bies.201000043/full

Genchev, N. 2001. Suppression of oriental fruit moth, Grapholita molesta (Lepidoptera: Tortricidae), populations using the sterile insect technique. In Evaluation of population suppression by irradiated Lepidoptera and their progeny. IAEA-D4 RC/561, Pulau Pinang, Malaysia.

Goldsmith, M. R. 1995. Genetics of the silkworm: revisiting an ancient model system, pp. 21-76. In M. R. Goldsmith and A. S. Wilkins (eds.), Molecular model systems in the Lepidoptera. Cambridge University Press, New York, NY, USA.

Goldsmith, M. R., and F. Marec (eds.). 2010. Molecular biology and genetics of the Lepidoptera. CRC Press, Boca Raton, FL, USA.

Gonnen, M., and M. Calderón. 1971. Effects of gamma radiation on Ephestia cautella (Walker) II. Effects on the progeny of irradiated males. Journal of Stored Products Research 7: 91-96.

González, J. R., and J. C. García. 1993. $F_{1}$ sterility of Diatraea saccharalis (Fab.), Lepidoptera: Crambidae. II. Mating dynamics and effects on progeny, pp. 419-426. In Proceedings: Management of Insect Pests: Nuclear and Related Molecular and Genetic Techniques. FAO/IAEA International Symposium, 19-23 October 1992, Vienna, Austria. STI/PUB/909. IAEA, Vienna, Austria. https:/www.iaea.org/publications/3782/management-of-insect-pests-nuclear-and-related-molecularand-genetic-techniques

Gonzales-Garcia, J. M., R. Benavente, and J. S. Rufas. 1996. Cytochemical and immunocytochemical characterization of kinetochores in the holocentric chromosomes of Graphosoma italicum. European Journal of Cell Biology 70: 352-360.

Graham, H. M., M. T. Ouye, R. D. Garcia, and H. H. de la Rosa. 1972. Dosages of gamma irradiation for full and inherited sterility in adult pink bollworms. Journal of Economic Entomology 65: 645-650.

Greany, P. D., and J. E. Carpenter. 2000. Use of nuclear techniques in biological control, pp. 221227. In K. H. Tan (ed.), Proceedings: Area-Wide Control of Fruit Flies and Other Insect Pests. International Conference on Area-Wide Control of Insect Pests, and the $5^{\text {th }}$ International Symposium on Fruit Flies of Economic Importance, 28 May-5 June 1998, Penang, Malaysia. Penerbit Universiti Sains Malaysia, Pulau Pinang, Malaysia. http://www-naweb.iaea.org/nafa/ipc/public/Area-wide-control_73-229.pdf

Guerra, A. A., and R. D. Garcia. 1976. Tobacco budworm: parental and inherited sterility induced by reserpine and gamma irradiation. Journal of Economic Entomology 69: 339-342.

Hamm, J. J., and J. E. Carpenter. 1997. Compatibility of nuclear polyhedrosis viruses and inherited sterility for control of corn earworm and fall armyworm (Lepidoptera: Noctuidae). Journal of Entomological Science 32: 148-153. https://doi.org/10.18474/0749-8004-32.2.148

Hendrichs, J., K. Bloem, G, Hoch, J. E. Carpenter, P. Greany, and A. S. Robinson. 2009. Improving the cost-effectiveness, trade and safety of biological control for agricultural insect pests using nuclear techniques. Biocontrol Science and Technology 19 (Supplement 1): S3-S22. https://doi.org/10.1080/09583150902985620

Henneberry, T. J. 1964. Effects of gamma radiation on the fertility of the twospotted spider mite and its progeny. Journal of Economic Entomology 57: 672-674. 
Henneberry, T. J., and T. Clayton. 1981. Effects on reproduction of gamma irradiated laboratoryreared pink bollworms and their $\mathrm{F}_{1}$ progeny after matings with untreated laboratory-reared or native insects. Journal of Economic Entomology 74: 19-23.

Hight, S. D., J. E. Carpenter, S. Bloem, and K. A. Bloem. 2005. Developing a sterile insect release program for Cactoblastis cactorum (Berg) (Lepidoptera: Pyralidae): effective overflooding ratios and release-recapture field studies. Environmental Entomology 34: 850-856. https://doi.org/10.1603/0046-225X-34.4.850

Hughes-Schrader, S., and F. Schrader. 1961. The kinetochore of the Hemiptera. Chromosoma 12: $327-350$.

Husseiny, M. M., and H. F. Madsen. 1964. Sterilization of the navel orangeworm, Paramyelois transitella (Walker) by gamma irradiation. Hilgardia 36: 113-117.

Jin, L., A. S. Walker, G. Fu, T. Harvey-Samuel, T. Dafa'alla, A. Miles, T. Marubbi, D. Granville, N. Humphrey-Jones, S. O'Connell, N. I. Morrison, and L. Alphey. 2013. Engineered femalespecific lethality for control of pest Lepidoptera. ACS Synthetic Biology 2: 160-166. http://pubs.acs.org/doi/abs/10.1021/sb300123m?journalCode=asbcd6

Kawamura, N., N. Yamashiki, and H. Bando. 1998. Behaviour of mitochondria during eupyrene and apyrene spermatogenesis in the silkworm, Bombyx mori (Lepidoptera), investigated by fluorescence in situ hybridization and electron microscopy. Protoplasma 202: 223-231.

Karpenko, C. P., and D. T. North. 1973. Ovipositional response elicited by normal, irradiated, $F_{1}$ sons, or castrated male Trichoplusia ni. Annals of the Entomological Society of America 66: 1278-1280.

Kean, J. M., D. M. Suckling, L. D. Stringer, and B. Woods. 2011. Modeling the sterile insect technique for suppression of light brown apple moth (Lepidoptera: Tortricidae). Journal of Economic Entomology 104: 1462-1475. https://doi.org/10.1603/EC11086

Kiuchi, T., H. Koga, M. Kawamoto, K. Shoji, H. Sakai, Y. Arai, G. Ishihara, S. Kawaoka, S. Sugano, T. Shimada, Y. Suzuki, M. G. Suzuki, and S. Katsuma. 2014. A single female-specific piRNA is the primary determiner of sex in the silkworm. Nature 509: 633-636. DOI: 10.1038/nature13315 http://www.nature.com/articles/nature13315

Knipling, E. F. 1964. The potential role of the sterility method for insect population control with special reference to combining this method with conventional methods, Series 33-98. USDA/ARS, Washington, DC, USA.

Knipling, E. F. 1970. Suppression of pest Lepidoptera by releasing partially sterile males: a theoretical appraisal. BioScience 20: 456-470.

Knipling, E. F. 1992. Principles of insect parasitism analyzed from new perspectives: practical implications for regulating insect populations by biological means, Agriculture Handbook Number 693. USDA/ARS, Washington, DC, USA.

Koudelová, J., and P. A. Cook. 2001. Effect of gamma radiation and sex-linked recessive lethal mutations on sperm transfer in Ephestia kuehniella (Lepidoptera: Pyralidae). Florida Entomologist 84: 172-182. http://www.fcla.edu/FlaEnt/fe84p172.pdf

Koval, T. M. 1996. Moths: myths and mysteries of stress resistance. BioEssays 18: 149-156.

LaChance, L. E. 1967. The induction of dominant lethal mutations in insects by ionizing radiation and chemicals - as related to the sterile-male technique of insect control, pp. 617-650. In J. W. Wright and R. Pal (eds.), Genetics of insect vectors of disease. Elsevier, Amsterdam, The Netherlands.

LaChance, L. E. 1974. Dominant lethal mutations in insects with holokinetic chromosomes. 2. Irradiation of sperm of cabbage looper. Annals of the Entomological Society of America 67: 35-39.

LaChance, L. E. 1985. Genetic methods for the control of lepidopteran species: status and potential, ARS-28. USDA/ARS, Washington, DC, USA.

LaChance, L. E., and M. Degrugillier. 1969. Chromosomal fragments transmitted through three generations in Oncopeltus (Hemiptera). Science 166: 235-236.

LaChance, L. E., and C. K. Graham. 1984. Insect radiosensitivity: dose curves and dose-fractionation studies of dominant lethal mutations in the mature sperm of 4 insect species. Mutation Research 127: 49-59.

LaChance, L. E., and R. Ruud. 1980. Genetics of the pink bollworm: an X-chromosome mutation affecting the expression of the purple-eye gene. Journal of Heredity 71: 437-438.

LaChance, L. E., C. H. Schmidt, and R. C. Bushland. 1967. Radiation-induced sterilization, pp. 147196. In W. W. Kilgore and R. L. Doutt (eds.), Pest control: biological, physical and selected chemical methods. Academic Press, New York, NY, USA. 
LaChance, L. E., M. Degrugillier, and A. P. Leverich. 1970. Cytogenetics of inherited partial sterility in three generations of the large milkweed bug as related to holokinetic chromosomes. Chromosoma 29: $20-41$.

LaChance, L. E., R. A. Bell, and R. D. Richard. 1973. Effect of low doses of gamma irradiation on reproduction of male pink bollworms and their $F_{1}$ progeny. Environmental Entomology 2: 653-658.

LaChance, L. E., R. D. Richard, and C. Belich. 1976. Inherited F1 sterility in the pink bollworm: effects on embryonic development and sperm transfer. Environmental Entomology 5: 543-548.

Leibenguth, F. 1986. Genetics of the flour moth, Ephestia kühniella. Agricultural Zoology Reviews 1: 39-72.

Li, Y. Y., H. Q. Zhang, H. Z. Lou, and C. D. Zhao. 1988. The inherited sterility of the corn borer (Ostrinia furnacalis Guen.), pp. 403-411. In Proceedings, Symposium: Modern Insect Control: Nuclear Techniques and Biotechnology. Food and Agriculture Organization of the United Nations, and International Atomic Energy Agency, 16-20 November 1987, Vienna, Austria. STI/PUB/763. IAEA, Vienna, Austria. https://www.iaea.org/sites/default/files/ipc-modern-insect-control.pdf

Light, D. M., I. Ovchinnikova, E. S. Jackson, and R. P. Haff. 2015. Effects of X-ray irradiation on male navel orangeworm moths (Lepidoptera: Pyralidae) on mating, fecundity, fertility, and inherited sterility. Journal of Economic Entomology 108: 2200-2212. https://doi.org/10.1093/jee/tov201

López-Martínez, G., J. E. Carpenter, S. D. Hight, and D. A. Hahn. 2016. Anoxia-conditioning hormesis alters the relationship between irradiation doses for survival and sterility in the cactus moth, Cactoblastis cactorum (Lepidoptera: Pyralidae). Florida Entomologist 99 (Special Issue 1): 95-104. http://journals.fcla.edu/flaent/article/view/88491

Ma, S., X. Wang, J. Fei, Y. Liu, J. Duan, F. Wang, H. Xu, P. Zhao, and Q. Xia. 2013. Genetic marking of sex using a W chromosome-linked transgene. Insect Biochemistry and Molecular Biology 43: 10791086. https://doi.org/10.1016/j.ibmb.2013.08.009

Makee, H. 1993. Recovery of fertility in irradiated Ephestia cautella (Walker) (Lepidoptera: Phycitidae), pp. 481-483. In Proceedings: Management of Insect Pests: Nuclear and Related Molecular and Genetic Techniques. FAO/IAEA International Symposium, 19-23 October 1992, Vienna, Austria. STI/PUB/909. IAEA, Vienna, Austria. https://www.iaea.org/publications/3782/management-of-insect-pests-nuclear-and-related-molecularand-genetic-techniques

Makee, H., and G. Saour. 1997. Inherited effects in $\mathrm{F}_{1}$ progeny of partially sterile male Pthorimaea operculella (Lepidoptera: Gelechiidae). Journal of Economic Entomology 90: 1097-1101.

Makee, H., M. Tlas, S. Amer, and J. Abdulla. 2007. Effect of inherited sterility and Bacillus thuringiensis on mortality and reproduction of Phthorimaea opercullela Zeller (Lepidoptera: Gelechiidae). Applied Entomology and Zoology 42: 557-562. http://doi.org/10.1303/aez.2007.557

Maksimovic, M. 1972. Two releases of sterile gypsy moth males (Lymantria dispar L.) in the park at Jelsa on the Island of Hvar. Zastita Bilja 23: 37-48.

Mannion, C. M., J. E. Carpenter, and H. R. Gross. 1994. Potential of the combined use of inherited sterility and a parasitoid, Archytas marmoratus (Diptera: Tachinidae), for managing Helicoverpa zea (Lepidoptera: Noctuidae). Environmental Entomology 23: 41-46.

Mannion, C. M., J. E. Carpenter, and H. R. Gross. 1995. Integration of inherited sterility and a parasitoid, Archytas marmoratus (Diptera: Tachinidae), for managing Helicoverpa zea (Lepidoptera: Noctuidae): acceptability and suitability of hosts. Environmental Entomology 24: 1679-1684.

Marec, F. 1990. Genetic control of pest Lepidoptera: induction of sex-linked recessive lethal mutations in Ephestia kuehniella (Pyralidae). Acta Entomologica Bohemoslovaca 87: 445-458.

Marec, F. 1991. Genetic control of pest Lepidoptera: construction of a balanced lethal strain in Ephestia kuehniella. Entomologia Experimentalis et Applicata 61: 271-283.

Marec, F. 1996. Synaptonemal complexes in insects. International Journal of Insect Morphology and Embryology 25: 205-233.

Marec, F., and R. Mirchi. 1990. Genetic control of the pest Lepidoptera: gamma-ray induction of translocations between sex chromosomes of Ephestia kuehniella Zeller (Lepidoptera: Pyralidae). Journal of Stored Products Research 26: 109-116.

Marec, F., and W. Traut. 1993a. Analysis of structural rearrangements of Lepidoptera chromosomes using the centrifugation spreading technique, pp. 243-250. In Proceedings: Management of Insect Pests: Nuclear and Related Molecular and Genetic Techniques. FAO/IAEA International Symposium, 19-23 October 1992, Vienna, Austria. STI/PUB/909. IAEA, Vienna, Austria. https://www.iaea.org/publications/3782/management-of-insect-pests-nuclear-and-related-molecularand-genetic-techniques 
Marec, F., and W. Traut. 1993b. Synaptonemal complexes in female and male meiotic prophase of Ephestia kuehniella (Lepidoptera). Heredity 71: 394-404.

Marec, F., J. Pavelka, J. Koudelová, V. Křivan, and P. A. Cook. 1996. Suppression of model populations of Ephestia kuehniella by releasing males balanced for two sex-linked recessive lethal mutations, pp. 39-51. In Evaluation of population suppression by irradiated Lepidoptera and their progeny. IAEA-D4 RC/561, Jakarta, Indonesia.

Marec, F., I. Kollárová, and J. Pavelka. 1999. Radiation-induced inherited sterility combined with a genetic sexing system in Ephestia kuehniella (Lepidoptera: Pyralidae). Annals of the Entomological Society of America 92: 250-259.

Marec, F., A. Tothová, K. Sahara, and W. Traut. 2001. Meiotic pairing of sex chromosome fragments and its relation to atypical transmission of a sex-linked marker in Ephestia kuehniella (Insecta: Lepidoptera). Heredity 87: 659-671. DOI: 10.1046/j.1365-2540.2001.00958.x http://www.nature.com/articles/6889580

Marec, F., L. G. Neven, A. S. Robinson, M. Vreysen, M. R. Goldsmith, J. Nagaraju, and G. Franz. 2005. Development of genetic sexing strains in Lepidoptera: from traditional to transgenic approaches. Journal of Economic Entomology 98: 248-259. https://doi.org/10.1093/jee/98.2.248

Marec, F., L. G. Neven, and I. Fukova. 2007. Developing transgenic sexing strains for the release of non-transgenic sterile male codling moths Cydia pomonella, pp. 103-111. In M. J. B. Vreysen, A. S. Robinson and J. Hendrichs (eds.), Area-wide control of insect pests. From research to field implementation. Springer, Dordrecht, The Netherlands. http://www-naweb.iaea.org/nafa/ipc/public/Area-Wide-Control-Insect-Pests-book.pdf

Marec, F., K. Sahara, and W. Traut. 2010. Rise and fall of the $\mathrm{W}$ chromosome in Lepidoptera, pp. 49-63. In M. R. Goldsmith and F. Marec (eds.), Molecular biology and genetics of the Lepidoptera. CRC Press, Boca Raton, FL, USA.

Mastro, V. C. 1993. Gypsy moth $F_{1}$ sterility program: current status, pp. 125-129. In Proceedings: Radiation Induced $\mathrm{F}_{1}$ Sterility in Lepidoptera for Area-Wide Control. Final Research Co-ordination Meeting, Joint FAO/IAEA Division of Nuclear Techniques in Food and Agriculture, 9-13 September 1991, Phoenix, AZ, USA. STI/PUB/929. IAEA, Vienna, Austria. http://www-naweb.iaea.org/nafa/ipc/public/ipc-radiation-inherited-sterility-area-wide-control.pdf

Mastro, V. C., T. M. Odell, and C. P. Schwalbe. 1989. Genetic control of Lymantriidae: prospects for gypsy moth management, pp. 275-302. In W. E. Wallner and K. A. McManus (eds.), Lymantriidae: a comparison of features of New and Old World tussock moths. U.S. Forestry Service General Technical Report NE-123, Washington, DC, USA.

Maudlin, I. 1976. The inheritance of radiation induced semi-sterility in Rhodnius prolixus. Chromosoma 58: 285-306.

Miller, E., R. T. Staten, E. Jones, and J. Pozzi. 1984. Effect of $20 \mathrm{krad}$ of gamma irradiation on reproduction of pink boll worm (Lepidoptera: Gelechiidae) and their $F_{1}$ progeny: potential impact on the identification of trap catches. Journal of Economic Entomology 77: 304-307. https://doi.org/10.1093/jee/77.2.304

Mitchell, E. R., H. Guangye, J. Okine, and J. E. Carpenter. 1999. Parasitism of diamondback moth (Lepidoptera: Plutellidae) larvae by Cotesia plutellae (Hymenoptera: Braconidae) and Diadegma insulare (Hymenoptera: Ichneumonidae) in cabbage fields after inundative releases of C. plutellae. Journal of Agricultural Entomology 34: 101-112.

Moeri, O. E., J. P. Cuda, W. A. Overholt, S. Bloem, and J. E. Carpenter. 2009. F $_{1}$ sterile insect technique: a novel approach for risk assessment of Episimus unguiculus (Lepidoptera: Tortricidae), a candidate biological control agent of Schinus terebinthifolius in the continental USA. Biocontrol Science and Technology 19 (Supplement 1): S303-S315. http://dx.doi.org/10.1080/09583150902741932

Mon, H., J. M. Lee, K. Mita, M. R. Goldsmith, and T. Kusakabe. 2014. Chromatin-induced spindle assembly plays an important role in metaphase congression of silkworm holocentric chromosomes. Insect Biochemistry and Molecular Biology 45: 40-50. https://doi.org/10.1016/j.ibmb.2013.11.007

Mudavanhu, P., P. Addison, J. E. Carpenter, and D. E. Conlong. 2016. Mating compatibility and competitiveness between wild and laboratory strains of Eldana saccharina (Lepidoptera: Pyralidae) after radiation treatment. Florida Entomologist 99 (Special Issue 1): 54-65. http://journals.fcla.edu/flaent/article/view/88486

Murakami, A. 1976. Inherited embryonic lethality in progeny of X-irradiated silkworm (Bombyx mori L.). Journal of Radiation Research 17: 46-47. 
Murakami, A., and H. T. Imai. 1974. Cytological evidence for holocentric chromosomes of the silkworms, Bombyx mori and B. mandarina, (Bombycidae, Lepidoptera). Chromosoma 47: 167-178.

Nabors, R. A., and C. D. Pless. 1981. Inherited sterility induced by gamma radiation in a laboratory population of the European corn borer, Ostrinia nubilalis. Journal of Economic Entomology 74: 701702

Nagaraju, J. 2000. Recent advances in molecular genetics of the silk moth, Bombyx mori. Current Science 78(2): 151-161. https://www.currentscience.ac.in/Downloads/article_id_078_02_0151_0161_0.pdf

Nguyen Thi, Q. H., and T. T. Nguyen Thanh. 2001. Radiation-induced $\mathrm{F}_{1}$ sterility in Plutella xylostella (Lepidoptera: Plutellidae): potential for population suppression in the field. Florida Entomologist 84: 199-208. http://www.fcla.edu/FlaEnt/fe84p199.pdf

Nielsen, R. A. 1971. Radiation biology of the greater wax moth (Galleria mellonella (L.)): effects on developmental biology, bionomics, mating-competitiveness, and $\mathrm{F}_{1}$ sterility. $\mathrm{PhD}$ thesis. Utah State University, Logan, UT, USA.

Nielsen, R. A., and C. D. Brister. 1980. Induced genetic load in descendants of irradiated greater wax moths. Annals of the Entomological Society of America 73: 460-467.

Nielsen, R. A., and E. N. Lambremont. 1976. Radiation biology of the greater wax moth: inherited sterility and potential for pest control. USDA Technical Bulletin Number 1539, Washington, DC.

Nilsson, N. O., C. Löfstedt, and L. Dävring. 1988. Unusual sex chromosome inheritance in six species of small ermine moths (Yponomeuta, Yponomeutidae, Lepidoptera). Hereditas 108: 259-265.

Nokkala, S. 1987. Cytological characteristics of chromosome behaviour during female meiosis in Sphinx ligustri L. (Sphingidae, Lepidoptera). Hereditas 106: 169-179.

North, D. T. 1967. Radiation-induced male sterility exhibited in the $P_{1}$ and $F_{1}$ generations in Lepidoptera. Radiation Research 31: 615.

North, D.T. 1975. Inherited sterility in Lepidoptera. Annual Review of Entomology 20: 167-182.

North, D. T., and G. G. Holt. 1968. Inherited sterility in progeny of irradiated male cabbage loopers. Journal of Economic Entomology 61: 928-931.

North, D. T., and G. G. Holt. 1969. Population suppression by transmission of inherited sterility to progeny of irradiated cabbage loopers, Trichoplusia ni. Canadian Entomologist 101: 513-520.

North, D. T., and G. G. Holt. 1970. Population control of Lepidoptera: the genetic and physiological basis. The Manitoba Entomologist 4: 53-69.

North, D. T., and J. W. Snow. 1978. Recovery of chromosome aberrations from natural populations of corn earworms and tobacco budworms subjected to daily releases of partially sterile moths. Journal of Economic Entomology 71: 358-360.

Ocampo, V. R. 2001. Effect of a substerilizing dose of radiation on the mating competitiveness of Helicoverpa armigera (Lepidoptera: Noctuidae). Florida Entomologist 84: 194-198. http://www.fcla.edu/FlaEnt/fe84p194.pdf

Ohbayashi, F., M. G. Suzuki, K. Mita, K. Okano, and T. Shimada. 2001. A homologue of the Drosophila doublesex gene is transcribed into sex-specific mRNA isoforms in the silkworm, Bombyx mori. Comparative Biochemistry and Physiology Part B: Biochemistry and Molecular Biology 128: 145-158. https://doi.org/10.1016/S1096-4959(00)00304-3

Okine, J. S., E. R. Mitchell, J. E. Carpenter, and G. Y. Hu. 1998. Oviposition response of Cotesia plutellae (Hymenoptera: Braconidae) to sterile and normal diamondback (Lepidoptera: Plutellidae) larvae and spatial dispersion of larvae on collard plants. Environmental Entomology 27: 1520-1524.

Omar, D., and M. Mansor. 1993. Effect of substerilization doses of radiation on the biology of diamondback moth, pp. 3-9. In Proceedings: Radiation Induced $F_{1}$ Sterility in Lepidoptera for AreaWide Control. Final Research Co-ordination Meeting, Joint FAO/IAEA Division of Nuclear Techniques in Food and Agriculture, 9-13 September 1991, Phoenix, AZ, USA. STI/PUB/929. IAEA, Vienna, Austria.

http://www-naweb.iaea.org/nafa/ipc/public/ipc-radiation-inherited-sterility-area-wide-control.pdf

Ostriakova-Varshaver, V. P. 1937. The bee moth, Galleria mellonella, as a new object for genetic investigations. II. Cytogenetic analysis of sterility initiated by X-rays in males. Biologicheskii Zhurnal 6: 816-836.

Peloquin J. J., S. T. Thibault, R. Staten, and T. A. Miller. 2000. Germ-line transformation of pink bollworm (Lepidoptera: Gelechiidae) mediated by the piggyBac transposable element. Insect Molecular Biology 9: 323-333.

http://onlinelibrary.wiley.com/doi/10.1046/j.1365-2583.2000.00194.x/abstract 
Pristavko, V. P., L. S. Plesskaya, B. G. Dectiarev, and L. V. Yanishevskaya. 1973. Influence of Xirradiation on the reproductive performance of $\mathrm{P}$ and $\mathrm{F}$ generations of the codling moth, Laspeyresia pomonella. Zoologicheskii Zhurnal 52: 1802.

Proshold, F. I. 1995. Remating by gypsy moths (Lepidoptera: Lymantriidae) mated with $F_{1}$-sterile males as a function of sperm within the spermatheca. Journal of Economic Entomology 88: 644-648.

Proshold, F. I., and J. A. Bartell. 1970. Inherited sterility in progeny of irradiated male tobacco budworms: effects on reproduction, developmental time, and sex ratio. Journal of Economic Entomology 63: 280-285.

Proshold, F. I., and J. A. Bartell. 1972a. Postembryonic growth and development of $F_{1}$ and $F_{2}$ tobacco budworms from partially sterile males. Canadian Entomologist 104: 165-172.

Proshold, F. I., and J. A. Bartell. 1972b. Inherited sterility and postembryonic survival of two generations of tobacco budworms, Heliothis virescens (Lepidoptera: Noctuidae), from partially sterile males. Canadian Entomologist 104: 221-230.

Proshold, F. I., and J. A. Bartell. 1973. Fertility and survival of tobacco budworms, Heliothis virescens, from gamma-irradiated females. Canadian Entomologist 105: 377-382.

Proshold, F. I., V. C. Mastro and G. L. Bernon. 1993. Sperm transfer by gypsy moths (Lepidoptera: Lymantriidae) from irradiated males: implication for control by inherited sterility. Journal of Economic Entomology 86: 1104-1108.

Proshold, F. I., H. R. Gross, and J. E. Carpenter. 1998. Inundative release of Archytas marmoratus (Diptera: Tachinidae) against the corn earworm and fall armyworm (Lepidoptera: Noctuidae) in whorl-stage corn. Journal of Entomological Science 33: 241-255.

Proverbs, M. D. 1962. Progress on the use of induced sexual sterility for the control of the codling moth Carpocapsa pomonella (L.) (Lepidoptera: Olethreutidae). Proceedings of the Entomological Society of Ontario 92: 5-11.

Proverbs, M. D., J. R. Newton, and D. M. Logan. 1978. Suppression of codling moth, Laspeyresia pomonella (Lepidoptera: Olethreutidae), by release of sterile and partially sterile moths. The Canadian Entomologist 110: 1095-1102. https://doi.org/10.4039/Ent1101095-10

Proverbs, M. D., J. R. Newton, and C. J. Campbell. 1982. Codling moth: a pilot program of control by sterile insect release in British Columbia. The Canadian Entomologist 114: 363-376. https://doi.org/10.4039/Ent114363-4

Qureshi, Z. A., N. Ahmed, and T. Hussain. 1993a. Rearing and gamma radiation effects on mature pupae of pink bollworm and their $F_{1}$ progeny, pp. 57-71. In Proceedings: Radiation Induced $F_{1}$ Sterility in Lepidoptera for Area-Wide Control. Final Research Co-ordination Meeting, Joint FAO/IAEA Division of Nuclear Techniques in Food and Agriculture, 9-13 September 1991, Phoenix, AZ, USA. STI/PUB/929. IAEA, Vienna, Austria. http://www-naweb.iaea.org/nafa/ipc/public/ipc-radiation-inherited-sterility-area-wide-control.pdf

Qureshi, Z. A., T. Hussain, and N. Ahmed. 1993b. Evaluation of the $F_{1}$ sterility technique for population suppression of the pink bollworm, Pectinophora gossypiella (Saunders), pp. 371-377. In Proceedings: Management of Insect Pests: Nuclear and Related Molecular and Genetic Techniques. FAO/IAEA International Symposium, 19-23 October 1992, Vienna, Austria. STI/PUB/909. IAEA, Vienna, Austria. https:/www.iaea.org/publications/3782/management-of-insect-pests-nuclear-andrelated-molecular-and-genetic-techniques

Rasmussen, S. W. 1977. The transformation of the synaptonemal complex into the "elimination chromatin" in Bombyx mori oocytes. Chromosoma 60: 205-221.

Riemann, J. G. 1973. Ultrastructure of sperm of $F_{1}$ progeny of irradiated males of the Mediterranean flour moth, Anagasta kuehniella. Annals of the Entomological Society of America 66: 147-153.

Rishi, S., G. Sahni, and K. K. Rishi. 1999. Inheritance of unusual sex chromosome evidenced by $\mathrm{AA}^{\mathrm{W}} \mathrm{Z}$ trivalent in Trabala vishnu (Lasiocampidae, Lepidoptera). Cytobios 100: 85-94.

Robinson, R. 1971. Lepidoptera genetics. Pergamon Press, Oxford, UK.

Rosca, I., and A. Barbulescu. 1990. Sterility inheritance in the irradiated European corn borer, Ostrinia nubilalis Hubner. Revue Roumaine de Biologie 35: 27-30.

Rosca, I., and A. Barbulescu. 1993. Evaluation of the potential control of the European corn borer (Ostrinia nubilalis $\mathrm{Hb}$.) in the field by radiation induced $\mathrm{F}_{1}$ sterility, pp. 379-394. In Proceedings: Management of Insect Pests: Nuclear and Related Molecular and Genetic Techniques. FAO/IAEA International Symposium, 19-23 October 1992, Vienna, Austria. STI/PUB/909. IAEA, Vienna. https:/www.iaea.org/publications/3782/management-of-insect-pests-nuclear-and-related-molecularand-genetic-techniques 
Sachdev, B., M. Zarin, Z. Khan, P. Malhotra, R. K. Seth, and R. K. Bhatnagar. 2014. Effect of gamma radiation on Phenoloxidase pathway, antioxidant defense mechanism in Helicoverpa armigera (Lepidoptera: Noctuidae) and its implication in inherited sterility towards pest suppression. International Journal of Radiation Biology 90: 7-19. http://dx.doi.org/10.3109/09553002.2013.835500

Saifutdinov, B. N. 1989. Cytogenetic estimation of inheritable partial sterility induced by gamma radiation in bollworm Heliothis armigera Hübn. Radiobiologia 29: 840-842.

Sallam, H. A., and S. M. Ibrahim. 1993. Inherited sterility in progeny of gamma irradiated male cotton leaf worm, Spodoptera littoralis (Boisd.), pp. 81-100. In Proceedings: Radiation Induced $\mathrm{F}_{1}$ Sterility in Lepidoptera for Area-Wide Control. Final Research Co-ordination Meeting, Joint FAO/IAEA Division of Nuclear Techniques in Food and Agriculture, 9-13 September 1991, Phoenix, AZ, USA. STI/PUB/929. IAEA, Vienna, Austria. http://www-naweb.iaea.org/nafa/ipc/public/ipc-radiation-inherited-sterility-area-wide-control.pdf

Sanford, W. J. 1976. Inherited sterility in progeny of irradiated male sugarcane borers. Journal of Economic Entomology 69: 456-458.

Sanford, W. J. 1977. Sugarcane borers: effect of sub-sterilizing doses of gamma irradiation on males irradiated as pupae or adults. Journal of Economic Entomology 70: 104-106.

Saour, G. 2016. Flight ability and dispersal of European grapevine moth gamma-irradiated males (Lepidoptera: Tortricidae). Florida Entomologist 99 (Special Issue 1): 73-78. http://journals.fcla.edu/flaent/article/view/88488

Schwartz, A. 1978. Die invloed van gammabestraling op valskodlingmot, Cryptophlebia leucotreta Meyr. Phytophylactica Pretoria 10: 37-42.

Seth, R. K., and S. E. Reynolds. 1993. Induction of inherited sterility in the tobacco hornworm Manduca sexta (Lepidoptera: Sphingidae) by substerilizing doses of ionizing radiation. Bulletin of Entomological Research 83: 227-235.

Seth, R. K., and S. S. Sehgal. 1993. Partial sterilizing radiation dose effect on the $F_{1}$ progeny of Spodoptera litura (Fabr.): growth bioenergetics and reproductive competence, pp. 427-440. In Proceedings: Management of Insect Pests: Nuclear and Related Molecular and Genetic Techniques. FAO/IAEA International Symposium, 19-23 October 1992, Vienna, Austria. STI/PUB/909. IAEA. https:/www.iaea.org/publications/3782/management-of-insect-pests-nuclear-and-related-molecularand-genetic-techniques

Seth, R. K., and V. P. Sharma. 2001. Inherited sterility by substerilizing radiation in Spodoptera litura (Lepidoptera: Noctuidae): Bio-efficacy and potential for pest suppression. Florida Entomologist 84: 183-193. http://www.fcla.edu/FlaEnt/fe84p183.pdf

Seth, R. K., Z. Khan, D. K. Rao, and M. Zarin. 2016a. Appraisal of sperm dynamics as a crucial trait of radiosterilized Spodoptera litura (Lepidoptera: Noctuidae) and its $F_{1}$ progeny for evaluation of the 'inherited sterility technique' for pest suppression. Florida Entomologist 99 (Special Issue 1): 105118. http://journals.fcla.edu/flaent/article/view/88492

Seth, R. K., Z. Khan, D. K. Rao, and M. Zarin. 2016b. Flight activity and mating behavior of irradiated Spodoptera litura (Lepidoptera: Noctuidae) males and their $\mathrm{F}_{1}$ progeny for use of inherited sterility in pest management approaches. Florida Entomologist 99 (Special Issue 1): 119-130. http://journals.fcla.edu/flaent/article/view/88493

Shang, H., and H. Lo. 1980. The inherited sterility of the European corn borer (Ostrinia nubilalis (Hübner)). China Agricultural Science 1: 70-73.

Sharma, K., A. Kumar, and S. Chandna. 2016. Constitutive hyperactivity of histone deacetylases enhances radioresistance in Lepidopteran Sf9 insect cells. Biochimica et Biophysica Acta 1860: 1237-1246. https://doi.org/10.1016/j.bbagen.2016.03.004

Shipp, E., A. W. Osborn, and P. B. Hutchinson. 1966. Radiation sterilization of sugar-cane leafhoppers of the family Delphacidae. Nature (London) 211: 98-99.

Soopaya, R., L. D. Stringer, B. Woods, A. E. A. Stephens, R. C. Butler, I. Lacey, A. Kaur, and D. M. Suckling. 2011. Radiation biology and inherited sterility of light brown apple moth (Lepidoptera: Tortricidae): developing a sterile insect release program. Journal of Economic Entomology 104: 1999-2008. https://doi.org/10.1603/EC11049

Steinitz, H., A. Sadeh, A. Kliot, and A. Harari. 2015. Effects of radiation on inherited sterility in the European grapevine moth (Lobesia botrana). Pest Management Science 71: 24-31. http://onlinelibrary.wiley.com/doi/10.1002/ps.3797/full 
Strom, B. L., F. P. Hain, and M. P. Ayres. 1996. Field performance of $F_{1}$-sterile gypsy moth larvae (Lepidoptera: Lymantriidae) on loblolly pine and sweetgum. Environmental Entomology 25: 749756. https://doi.org/10.1093/ee/25.4.749

Strunnikov, V. A. 1975. Sex control in silkworms. Nature 255: 111-113.

Suckling, D. M., J. K. Hackett, A. M. Barrington, and J. M. Daly. 2002. Sterilisation of painted apple moth Teia anartoides (Lepidoptera: Lymantriidae) by irradiation. New Zealand Plant Protection 55: 7-11. http://www.hortnet.co.nz/publications/nzpps/proceedings/02/02_007.pdf

Sugai, E., and M. Mirumachi. 1973. Inherited sterility in progeny of irradiated male silkworms, Bombyx mori L. Japanese Journal of Genetics 48: 329-335.

Suman, S., Z. Khan, M. Zarin, S. Chandna, and R. K. Seth. 2015. Radioresistant Sf9 insect cells display efficient antioxidant defence against high dose $\gamma$-radiation. International Journal of Radiation Biology 91: 732-741. http://dx.doi.org/10.3109/09553002.2015.1054958

Suomalainen, E. 1969a. Chromosome evolution in the Lepidoptera. Chromosomes Today 2: 132-138.

Suomalainen, E. 1969b. On the sex chromosome trivalent in some Lepidoptera females. Chromosoma 28: $298-308$.

Sutrisno Apu, S. 2001. The use of $F_{1}$ sterility and parasitoids for suppression of lepidopteran pests of crucifers in Indonesia. In Evaluation of population suppression by irradiated Lepidoptera and their progeny. IAEA-D4 RC/561, Pulau Pinang, Malaysia.

Sutrisno Apu, S., and S. Hoedaya. 1993. The sterile insect technique and transmission of inherited sterility to control the diamondback moth, Plutella xyllostela (L.) and the cabbage webworm, Crocidolomia binotalis Zell., pp. 395-403. In Proceedings: Management of Insect Pests: Nuclear and Related Molecular and Genetic Techniques. FAO/IAEA International Symposium, 19-23 October 1992, Vienna, Austria. STI/PUB/909. IAEA, Vienna, Austria.

www.iaea.org/publications/3782/management-of-insect-pests-nuclear-and-related-molecular-andgenetic-techniques

Sutrisno Apu, S., S. Hoedaya, M. Sutardji, and A. Rahayu. 1993. Radiation induced $F_{1}$ sterility in diamondback moth, Plutella xylostella, and tropical armyworm, Spodoptera litura, pp. 23-26. In Proceedings: Radiation Induced $F_{1}$ Sterility in Lepidoptera for Area-Wide Control. Final Research Co-ordination Meeting, Joint FAO/IAEA Division of Nuclear Techniques in Food and Agriculture, 9-13 September 1991, Phoenix, AZ, USA. STI/PUB/929. IAEA, Vienna, Austria.

http://www-naweb.iaea.org/nafa/ipc/public/ipc-radiation-inherited-sterility-area-wide-control.pdf

Suzuki, M. G. 2010. Sex determination: insights from the silkworm. Journal of Genetics 89: 357-363. http://www.ias.ac.in/article/fulltext/jgen/089/03/0357-0363

Tamura T., C. Thibert, C. Royer, T. Kanda, E. Abraham, M. Kamba, N. Komoto, J. L. Thomas, B. Mauchamp, G. Chavancy, P. Shirk, M. Fraser, J. C. Prudhomme, and P. Couble. 2000. Germline transformation of the silkworm Bombyx mori L. using a piggyBac transposon-derived vector. Nature Biotechnology 18: 81-84. DOI: 10.1038/71978 http://www.nature.com/articles/nbt0100_81

Tan, A., G. Fu, L. Jin, Q. Guo, Z. Li, B. Niu, Z. Meng, N. I. Morrison, L. Alphey, and Y. Huang. 2013. Transgene-based, female-specific lethality system for genetic sexing of the silkworm, Bombyx mori. Proceedings of the National Academy of Sciences of the United States of America 110: 67666770. DOI: 10.1073/pnas.1221700110 http://www.pnas.org/content/110/17/6766

Tate, C. D., S. D. Hight, and J. E. Carpenter. 2009. Oviposition preference of Cactoblastis cactorum (Lepidoptera: Pyralidae) in caged choice experiments and the influence on risk assessment of $\mathrm{F}_{1}$ sterility. Biocontrol Science and Technology 19 (Supplement 1): S317-S333. http://dx.doi.org/10.1080/09583150902814507

Tazima, Y. 1964. The genetics of the silkworm. Academic Press, London, UK.

Toba, H. H., A. N. Kishaba, and D. T. North. 1972. Reduction of populations of caged cabbage loopers by release of irradiated males. Journal of Economic Entomology 65: 408-411.

Tothová, A., and F. Marec. 2001. Chromosomal principle of radiation-induced $\mathrm{F}_{1}$ sterility in Ephestia kuehniella (Lepidoptera: Pyralidae). Genome 44: 172-184. https://doi.org/10.1139/g00-107

Traut, W. 1977. A study of recombination, formation of chiasmata and synaptonemal complexes in female and male meiosis of Ephestia kuehniella (Lepidoptera). Genetica 47: 135-142.

Traut, W. 1986. A genetic linkage study of W-chromosome-autosome fusions, breakage, and kinetic organization of chromosomes in Ephestia (Lepidoptera). Genetica 69: 69-79.

Traut, W., and F. Marec. 1996. Sex chromatin in Lepidoptera. Quarterly Review of Biology 71: 239256. 
Traut, W., and F. Marec. 1997. Sex chromosome differentiation in some species of Lepidoptera (Insecta). Chromosome Research 5: 283-291.

Traut, W., K. Sahara, and F. Marec. 2007. Sex chromosomes and sex determination in Lepidoptera. Sexual Development 1: 332-346. https://doi.org/10.1159/000111765

Vreysen, M. J. B., W. Klassen, and J. E. Carpenter. 2016. Overview of technological advances toward greater efficiency and efficacy in sterile insect-inherited sterility programs against moth pests. Florida Entomologist 99(Special Issue 1): 1-12. https://journals.flvc.org/flaent/article/view/88480/84948

Wakid, A. F. M., and J. M. Hayo. 1974. Inherited sterility in progeny of irradiated male cotton leaf worm, Spodoptera littoralis Bois. Zeitschrift für Angewandte Entomologie 76: 331-335.

Walker, D. W., and K. B. Pederson. 1969. Population models for suppression of the sugarcane borer by inherited partial sterility. Annals of the Entomological Society of America 62: 21-26.

Walker, D. W., and V. Quintana. 1968a. Inherited partial sterility among survivors from irradiationeradication experiment. Journal of Economic Entomology 61: 318-319.

Walker, D. W., and V. Quintana. 1968b. Mortality staging of dominant lethals induced in the $F_{1}$ generation of the sugarcane borer, Diatraea saccharalis (F.). Radiation Research 26: 138-143.

Walker, D. W., V. Quintana, and J. Torres. 1971. Genetic collapse of insect populations. 1. Extinction of inbred and outbred lines in laboratory populations of the sugarcane borer. Journal of Economic Entomology 64: 660-667.

Walton, A. J., and D. E. Conlong. 2016. Radiation biology of Eldana saccharina (Lepidoptera: Pyralidae). Florida Entomologist 99 (Special Issue 1): 36-42. http://journals.fcla.edu/flaent/article/view/88484

Wang, H. S., Q. R. Liu, D. G. Lu, E. D. Wang, W. Kang, X. H. Liu, Y. J. Li, Q. L. He, and H. Q. Zhang. 2001. Radiation-induced substerility of Ostrinia furnacalis (Lepidoptera: Pyralidae) integrated with the release of Trichogramma ostriniae (Hymenoptera: Trichogrammatidae) for areawide control. In Evaluation of population suppression by irradiated Lepidoptera and their progeny. IAEA-D4 RC/561, Pulau Pinang, Malaysia.

Wee, S. L., D. M. Suckling, G. M. Burnip, J. Hackett, A. Barrington, and R. Pedley. 2005. Effects of substerilizing doses of gamma radiation on adult longevity and level of inherited sterility in Teia anartoides (Lepidoptera: Lymantriidae). Journal of Economic Entomology 98: 732-738. https://doi.org/10.1603/0022-0493-98.3.732

Weith, A., and W. Traut. 1980. Synaptonemal complexes with associated chromatin in a moth, Ephestia kuehniella Z.: the fine structure of the W chromosomal heterochromatin. Chromosoma 78 : 275-291.

White, L. D. 1975. Codling moth: effects of sterilizing and substerilizing levels of gamma irradiation to the sperm on $F_{1}$ egg development. Journal of Economic Entomology 68: 845-846.

Wolf, K. W. 1994. The unique structure of Lepidopteran spindles. International Review of Cytology 152: $1-48$.

Wolf, K. W. 1996. The structure of condensed chromosomes in mitosis and meiosis of insects. International Journal of Insect Morphology and Embryology 25: 37-62.

Wolf, K. W., and W. Traut. 1991. Cytology of Lepidoptera. VII. The restructuring of eupyrene prophase I spermatocytes and its relationship to meiotic chromosome and spindle organization in Ephestia kuehniella Z. Protoplasma 165: 51-63.

Wolf, K. W., K. Novák, and F. Marec. 1997. Kinetic organization of metaphase I bivalents in spermatogenesis of Lepidoptera and Trichoptera species with small chromosome numbers. Heredity 79: $135-143$.

Wong, T. T. Y., M. M Ramadan, J. C. Herr, and D. O. McInnis. 1992. Suppression of a Mediterranean fruit fly (Diptera: Tephritidae) population with concurrent parasitoid and sterile fly releases in Kula, Maui, Hawaii. Journal of Economic Entomology 85: 1671-1681.

Woods, B., D. McInnis, E. Steiner, A. Soopaya, J. Lindsey, I. Lacey, A. Virdi, and R. Fogliani. 2016. Developing field cage tests to measure mating competitiveness of sterile light brown apple moths (Lepidoptera: Tortricidae) in Western Australia. Florida Entomologist 99 (Special Issue 1): 138-145. http://journals.fcla.edu/flaent/article/view/88495

Wrensch, D. L., J. B. Kethley, and R. A. Norton. 1994. Cytogenetics of holokinetic chromosomes and inverted meiosis: keys to the evolutionary success of mites, with generalizations on eukaryotes, pp. 282-343. In M. A. Houck (ed.), Mites: ecological and evolutionary analyses of life-history patterns. Chapman and Hall, New York, NY, USA. 
Zhang, H. Q., Y. Y. Li, W. Kang, H. S. Wang, and W. Zhang. 1993. Studies on chromosomal aberrations and inherited sterility in Asian corn borer, Ostrinia furnacalis Guenee, pp. 117-124. In Proceedings: Radiation Induced $F_{1}$ Sterility in Lepidoptera for Area-Wide Control. Final Research Co-ordination Meeting, Joint FAO/IAEA Division of Nuclear Techniques in Food and Agriculture, 9-13 September 1991, Phoenix, AZ, USA. STI/PUB/929. IAEA, Vienna, Austria.

http://www-naweb.iaea.org/nafa/ipc/public/ipc-radiation-inherited-sterility-area-wide-control.pdf

Zhang, K., H. Fu, S. Zhu, Z. Li, Q. F. Weng, and M. Y. Hu. 2016. Influence of gamma-irradiation on flight ability and dispersal of Conopomorpha sinensis (Lepidoptera: Gracillariidae). Florida Entomologist 99 (Special Issue 1): 79-86. http://journals.fcla.edu/flaent/article/view/88489 